\title{
Le Corbusier's Postcard Collection: Poetical Assemblage as a "Porous" Classification System
}

Luis Burriel Bielza,

Ecole Nationale Supérieure d'Architecture de Paris-Belleville

\begin{abstract}
Le Corbusier collected about 2,300 postcards throughout all of his life but he always kept them secretly stored in his apartment. They are nowadays held in the archives of the Fondation Le Corbusier, filed by geographic origin. However, this system is not suited to unravel its signification. Through a new associative layout, this article strives to highlight its proper value and aspires to place them fully connected to his other creative tools. Accompanied by his paintings, sketches, writings, and architecture, they will all reveal Le Corbusier's capacity to synthesize subjects and concepts regardless of time and space. Stability and transition are the guiding keys to jump from image to image, at the same time charged with the power of evoking the tradition and building the present. The concept of "poetical assemblage" will prove that three main goals are intermingled in growing degrees: inspiration, education and verification.
\end{abstract}

KEYWORDS: assemblage, collection, imagery, Le Corbusier, postcards

Up to this point, Le Corbusier's original sources of inspiration have been at the core of very wellknown research projects, ${ }^{1}$ but always through the study of documents he compiled at the beginning of his career, while this collection covers his whole life. Despite their number, these postcards have never attracted the proper attention they deserve. Stanislaus von Moos unveiled a very specific approach strictly attached to four postcards related to the subject in "Women from Algiers" (Von Moos, 1987, p. 26) and while some of this material has been exhibited, it was always portrayed as mere souvenirs from a tourist, not providing any clear direction regarding its meaning. This lack of interest is partially explained by the fact that Le Corbusier hardly ever mentioned its existence ${ }^{2}$ and also that he never wrote anything upon this material, which he kept stored away in his apartment. The specimens collected were not postcards sent or received by the architect. ${ }^{3}$ This text strives to highlight their real value by two different means: First, proposing a new assemblage and second, placing this collection in connection with other creative tools. The postcards are nowadays stored at the Fondation Le Corbusier, classified following a typical category within deltiology: geographical origin. However, when studying some items of this collection during my $\mathrm{PhD}$ research (focusing on the project for the parish church of Saint Pierre in Firminy), the relations I uncovered gave me the certitude that its scope could hardly be articulated after its current classification, especially given the fact that the architect did not have any particular training in this discipline. This unfamiliarity might have led him to cast a superficial analysis on the matter, but this distance also allowed him to work completely rid of preconceived ideas, thereby amplifying the concealed possibilities of the physical medium which becomes a triggering device.

In an interview I held with his former collaborator José Oubrerie, he reported that Le Corbusier's frequent trips were the opportunity to buy these postcards, which were then arranged in chronological order following the time of acquisition. Based on this assessment, the current system moves away from the initial classification conceived by the architect. However, our main goal is not to restore their original placement. There is a need to propose an alternative system, that of an associative choreography: a layout of images organized in order to reveal their connections, so as to re-introduce and present other scholars with a neglected and powerful source of research. For Le Corbusier, when making use of images (sketches, photographs, and postcards), "analysis" and "synthesis" share the same level, bringing into harmony both approaches in one single operation. This procedure is truly sustained by the ideas found in his personal copy of Dr. Alexis Carrel's book Man, The Unknown, where he underlined the following paragraph: 
Wise geniuses, besides the power to observe and to understand, have other qualities such as intuition and creative imagination. By intuition, they grasp what is hidden to other men, they see connections between seemingly isolated phenomena, they sense the existence of the ignored treasure. (Carrel, 1936, p. 143) ${ }^{4}$

His atelier at Rue de Sèvres in Paris (Figure 1) shall help us to understand this creative process: plans, drawings and models of different projects coexisted and blended to create a highly charged working atmosphere, where ideas were shared and tested in several experimental situations. But also in his Paris apartment at 24 Rue Nungesser et Coli (Figure 2), this same feeling pervades the air: paintings, drawings, enamels, sketches, collages... different media intermingled in apparent disarray.
The main task to accomplish with this collection is to overcome the current classification system in order to provide a new framework, a new tool with the ability to reveal the creative process of its owner. This vision should then be extended to absorb and incorporate other tools of research in the second phase of this text, but on which grounds? The accumulation of documents in his Atelier shall be understood rather as an "organized stratification," helping the architect to articulate his obsessions. This pile of paper made sense according to an invisible frame, corresponding to an internal process that was destroyed or distorted by dispersing all these pieces in separate folders.

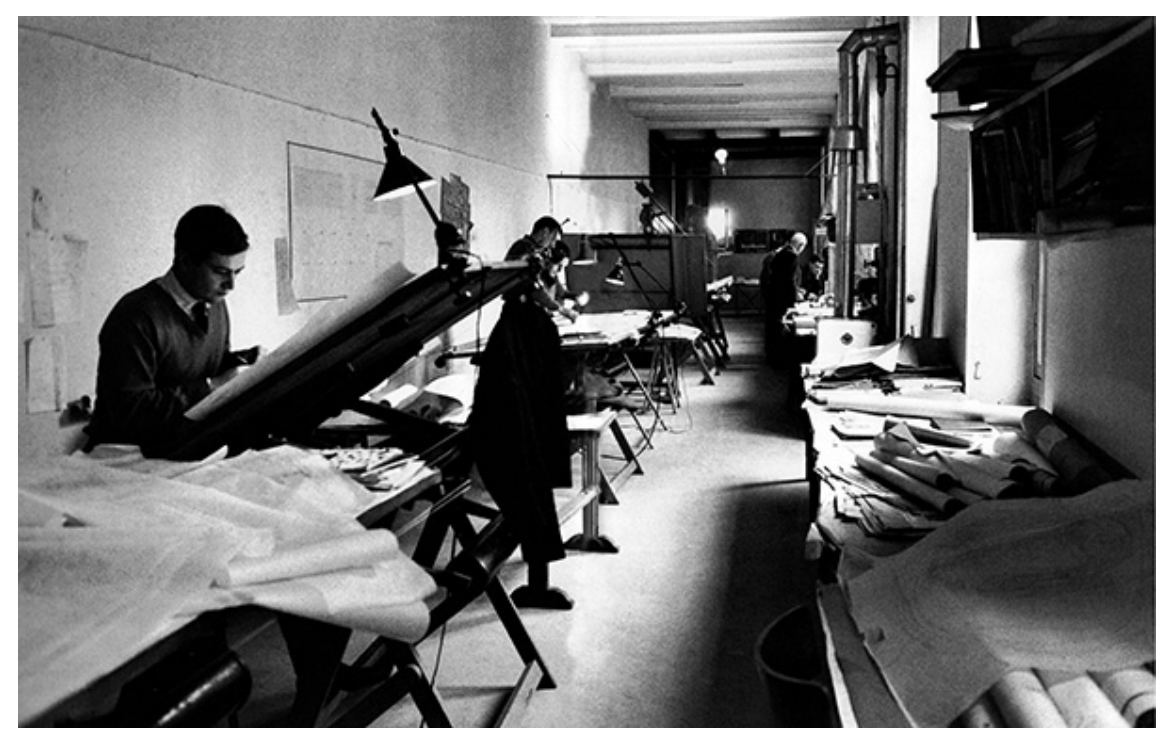

Figure 1. Le Corbusier's atelier at 35 Rue de Sèvres around 1960

Figure 2. Le Corbusier's apartment at 24 Rue Nungesser et Coli around 1964

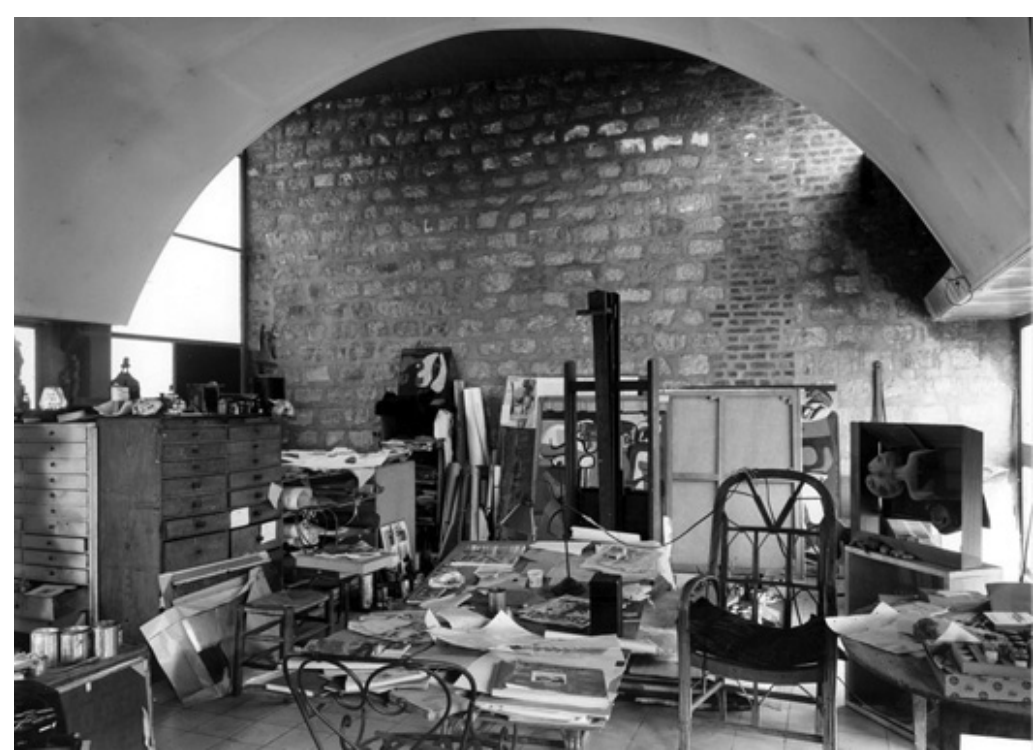


In July 1935, Le Corbusier presented an exhibition called "Primitive Art in the Modern House", organized along with art collector Louis Carré. Quite surprisingly, it took place in the architect's apartment and extended through some other flats. It comprised several works from contemporary artists such as Fernand Léger and Henry Laurens, establishing a fruitful dialog with classical or folk objects (brought by Le Corbusier after his initial voyage to the East ${ }^{5}$ ), or even others found in nature which he named as "objects of poetic reaction". Despite its domestic size, it was certainly important enough to be included in his Complete Works 1934-1938, along with this short text:

The grouping technique is some sort of a demonstration of modern sensibility in the consideration of the past, the exoticism or the present, recognizing "series", creating "units" across time and space. Giving a palpitating view of the things where man has registered its presence. (Le Corbusier, 1938, p. 128)

The exhibition was a true manifesto: his way of understanding our present completely connected and embedded within a much larger historical context, reverberating in tune with our past and traditions. I believe this specific approach is the key to understanding the value of his postcard collection and, by extension, the construction of his poetical universe.
Collecting postcards should also be considered as an activity born under the same methodology, where the true value of each specimen grows from the connections established between the different pieces of the collection. Besides, any other working and inspirational sources developed by its owner will be included in this research in order to reinforce and test the hypothesis already developed in his 1935 exhibition. This will allow to establish a transversal view over his life, reinforcing the inner consistency of his overall production. Thus, this research comprised documents from six different sources:

\section{Drawings and sketches}

2. Paintings, tapestries and enamels

3. Agendas and Sketchbooks

4. Photographs

5. Publications, writings and books

6. Architectural projects

Through this fruitful dialogue, postcards reveal themselves as "poetic images" following Le Corbusier's understanding, but also supporting the definition brought much later on by Juhani Pallasmaa: "poetic images make reference to an evocative, affective and meaningful sensorial experience, which is associative and dynamic, formed by different layers and which is constantly interacting with memory and desire" (Pallasmaa, 2011, p. 42). Here, two terms are really meaningful for our purpose: associative and

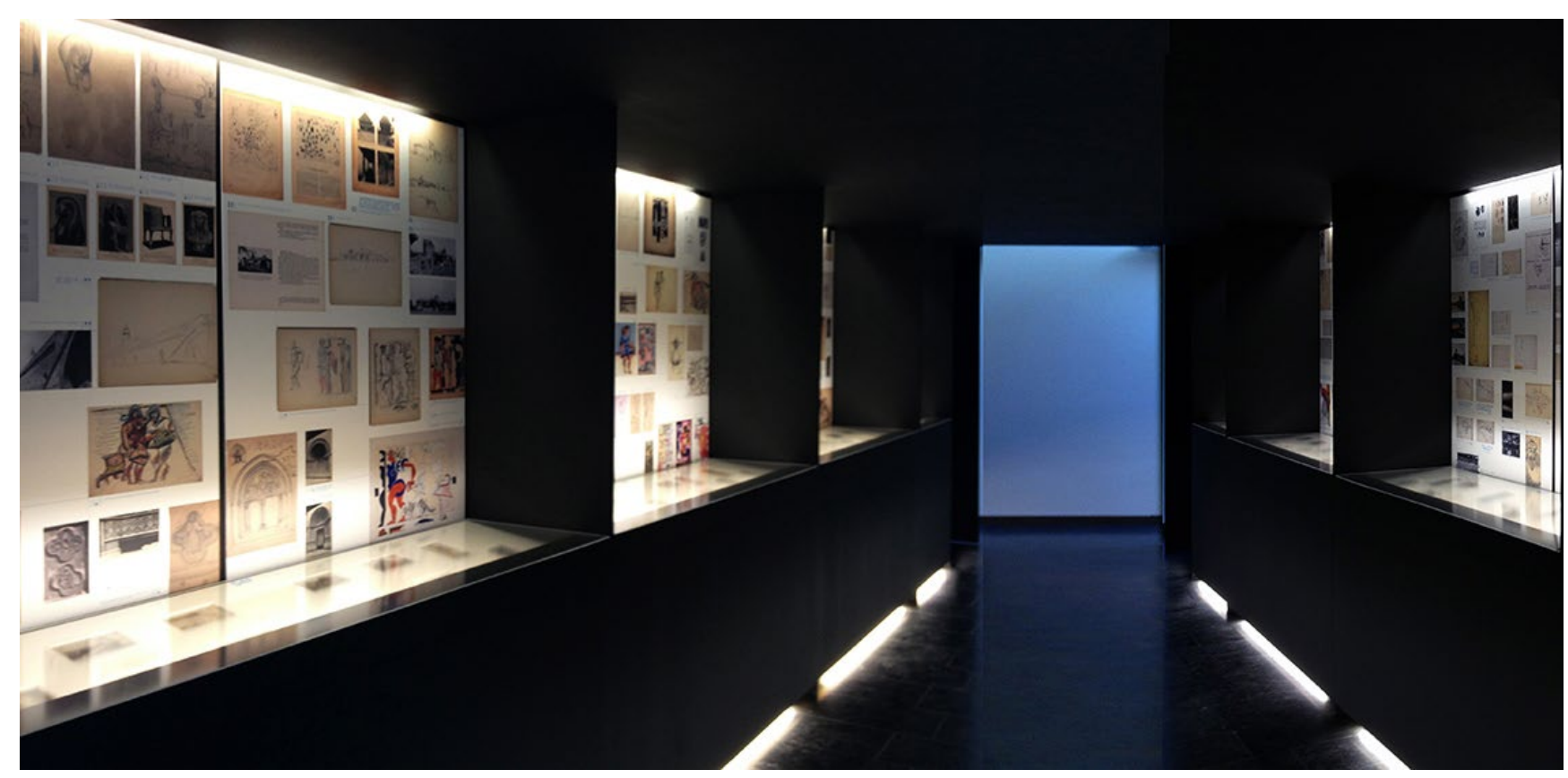

Figure 3. The exhibition “Le Corbusier: la passion des cartes”, CIVA Museum, Brussels, April $26^{\text {th }}-0$ ctober $6^{\text {th }} 2013$ 
dynamic. They both propose relations which are neither hermetic nor exclusive. Working on the collection as a hermetically sealed entity with an internal logic univocally addressed, or failing to establish connections with any other medium limits our understanding, out of Le Corbusier's multidimensional scope. This is in fact an ongoing and open research, which strives to attract the attention from other researchers willing to push forward and show the validity of the notion of "poetical assemblage" when applied to this collection.

The way in which the architect's 1935 exhibition presented a whole array of objects from different times and countries provided a strong clue in order to approach, analyze and re-classify this material, but even more, to develop and present the results of this research through a traveling exhibition first held at the CIVA Museum in Brussels in 2013 (Figure 3).

In order to frame this research, the exhibition was presented as a constellation of images gravitating around one question: the balance between two main concepts necessary to understand Le Corbusier's creative process and by extension, the way in which he perceived our world. These two concepts are stability and transition, i.e., the permanence and continuity of certain ideas through the history of our civilization and later on, the necessary reinterpretation in order to transfer, to re-elaborate and to revitalize these same issues in our contemporary world. As a microcosm, his architecture should be framed within this double dimension: it aspired to be part of the ancient tradition in the same way the timeless "standards" he defined in his book Almanach d'architecture moderne (Le Corbusier, 1926, p. 83-90), and also, it was conceived to give an adequate response to the needs of modern man within an industrial society.

In the exhibition, four initial sections are proposed so as to control and organize the different means of expression: Youth travels / Sketchbooks / Writings / Drawings. In fact these are truly a sort of operational layers superimposed over the iconographical material. 168 postcards are displayed, i.e., only $7 \%$ of the total amount. The postcards, displayed horizontally, are engaged into an active exchange with 28 vertical panels containing nearly 600 documents from the archives, all drawn, collected, written and developed by the architect himself. His architectural works are found completely immersed in the same creative whirlwind, irrigated by the same associative energy. Thus, it is not surprising to find traces connecting his projects with structural, morphological and typological issues that have been discovered, borrowed, recovered or reworked from postcards. Those "traces" evolve into "patterns" or "themes" that help to understand their insertion, their façades, their internal circulations and ultimately, their inner coherence, which rests in the fact that the solution is not the answer to an isolated question but rather the result of an ongoing process, engaged with different tools. As the layout of the exhibition reveals, dissecting and presenting the collection and its results to the public will coincide conceptually and formally: "working" and "communicating" share the same methodology for this research. As opposed to a "classification" issued from deltiology, the "maps" shown on Figure 3 help to unfold the notion of "poetical assemblage": images achieve a new meaning through dynamic associations activated by the place they occupy, multiplying their connotations.

The panels of the exhibition compose an "iconographic topography" that reveals Le Corbusier's approach to his collection. Three main purposes appear, supported by examples where all of them coexist combined in different degrees:

1. Inspiration in the construction of Le Corbusier's poetic and vocabulary imagery

2. Education to understand the world around him, to incorporate the tradition

3. Ratification and authentication of his research under the light of ancient models 


\section{INSPIRATION IN THE CONSTRUCTION OF LE CORBUSIER'S POETIC IMAGERY}

His paintings clearly offer an outstanding proof for the appropriation of different subjects contained in postcards exclusively based on formal manipulation. The hand of the architect performs this transformation.

The interlaced couple (Figure 4) turns into this 1938 painting portraying two colorful female figures (Figure 5), moving through different trials until it finally morphs into this awkward self-embracing being (Figure 6) found in his 1955 book The Poem of the Right Angle (Le Corbusier, 1955, p. 92). This trip traces a formal research that will be used on several occasions. Repeating the contours of these "objects" in enchained stages gives rise to a new silhouette. In this way, Le Corbusier is able to create an extremely personal calligraphy, where the original postures are recognized but where the linear features acquire their own formal autonomy. The postcards are a starting point from which he can

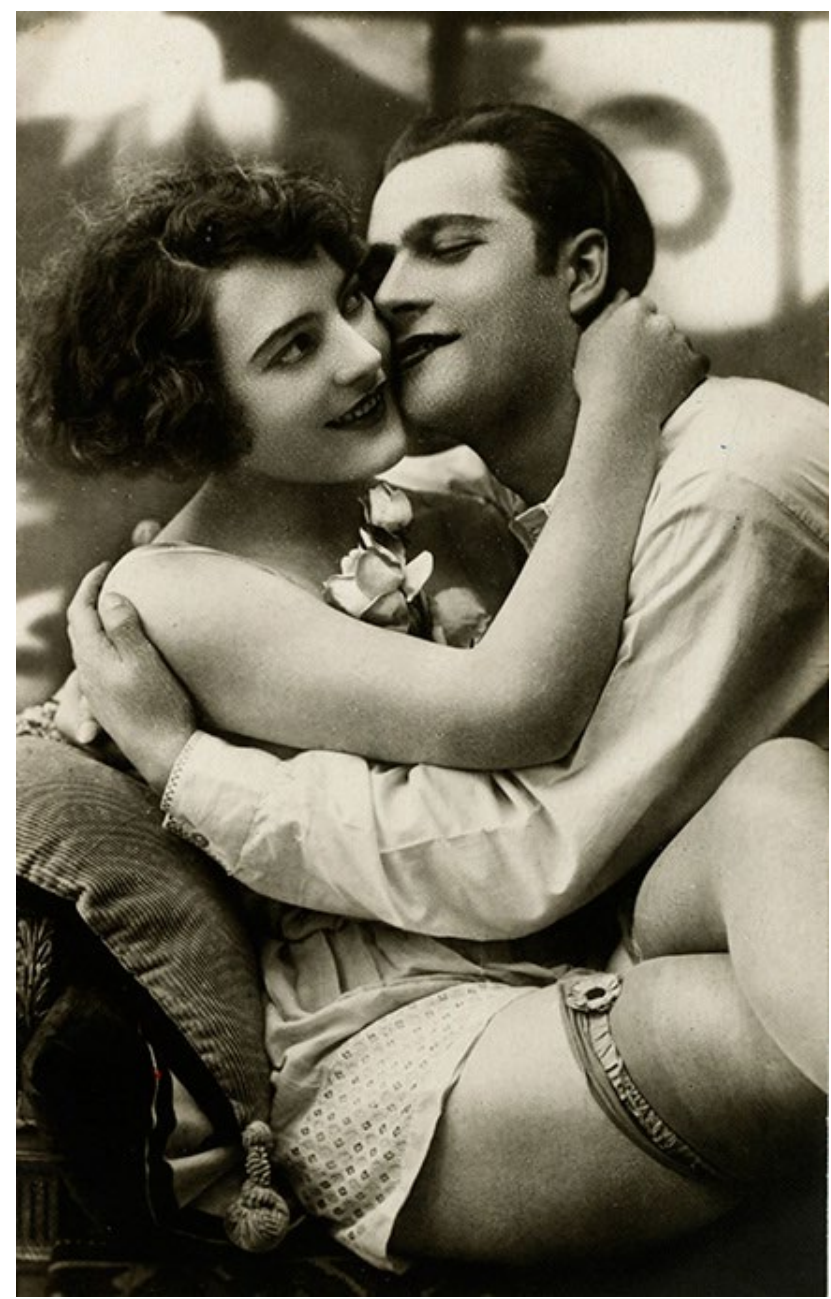

Figure 4.Couple embracing each other, postcard, n.d. develop a first draft that respects, to a large extent, the original pattern and develops in successive phases to build his personal vocabulary. Through subsequent iteration, superposition, reverberation, stratification, addition and juxtaposition, the original postcard transmutes, sometimes even incorporating subjects from other postcards generating new compositions, as in his architecture.

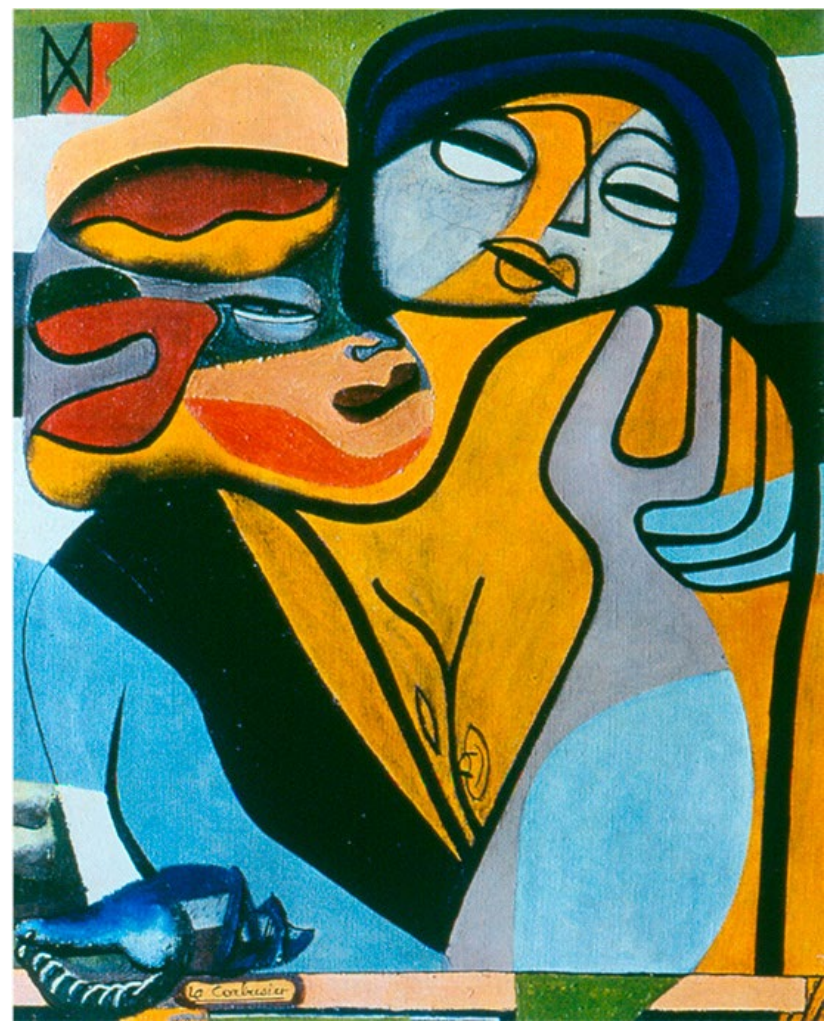

Figure 5.Two Women, 1938, oil on canvas, painting.

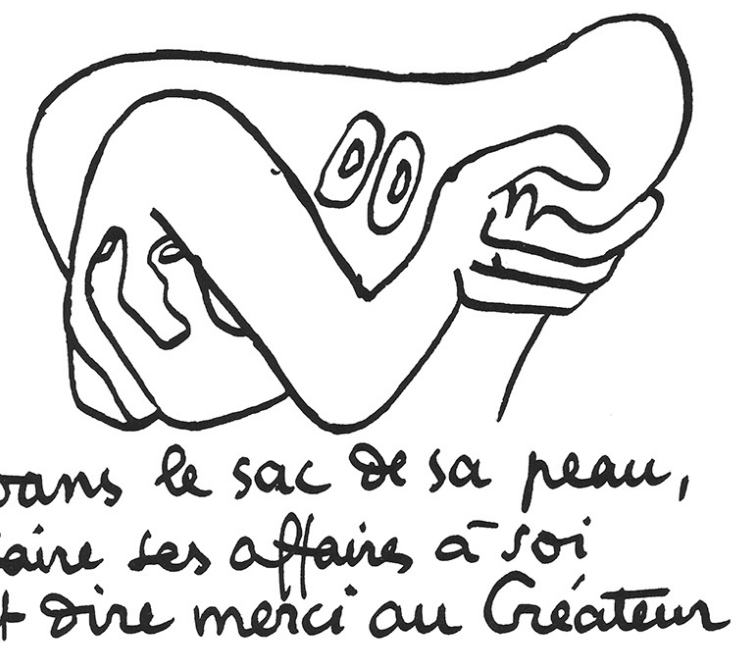

Figure 6.Illustration from Le Corbusier. (1955) Poème de l'angle droit. Paris: Verve 


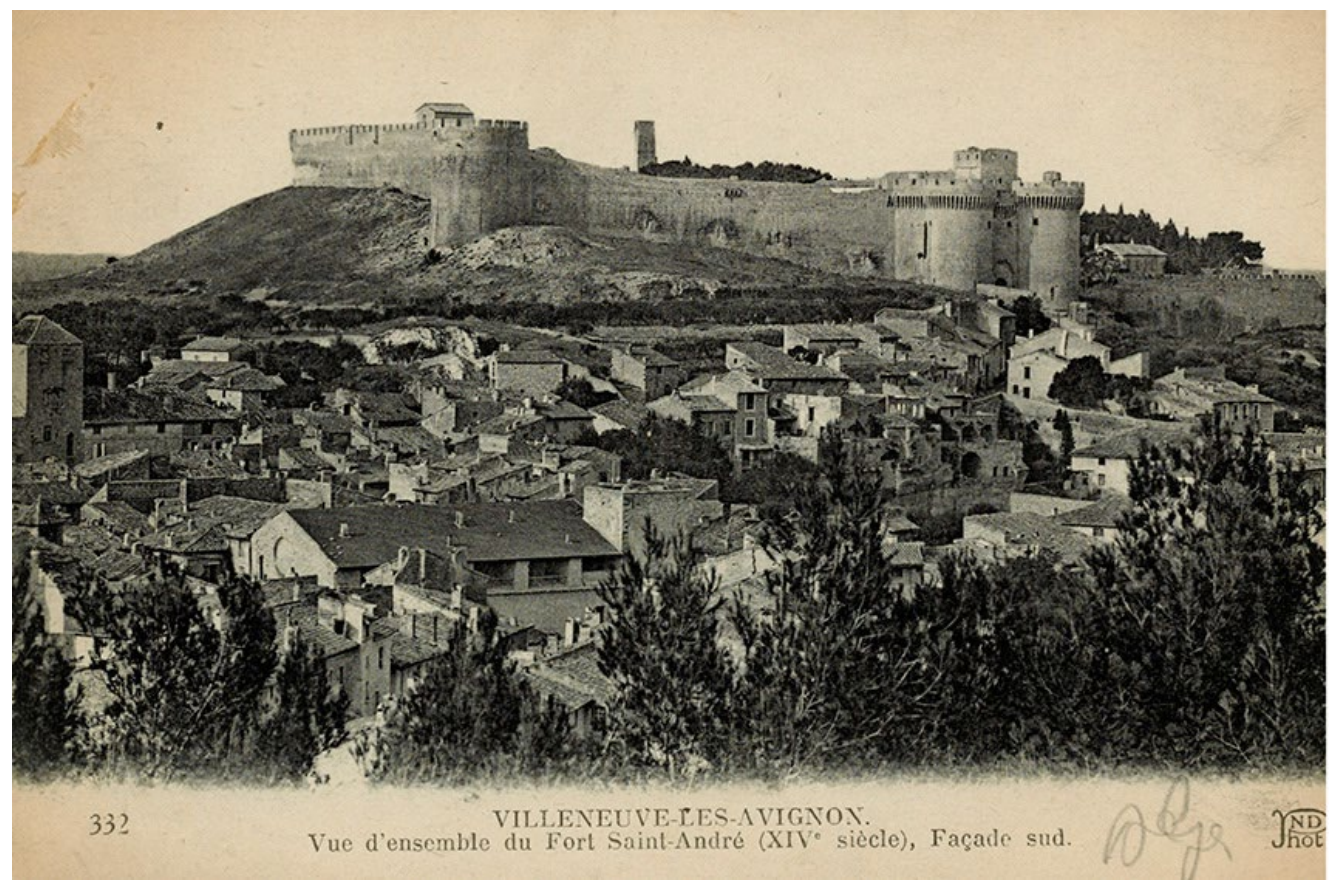

Figure 7. General overview of Saint-André's Fortress (XIVth century), south facade, Villeneuve-les-Avignon (France), postcard, n.d.

Figure 8. Citadel, Perpignan (France), postcard, n.d.

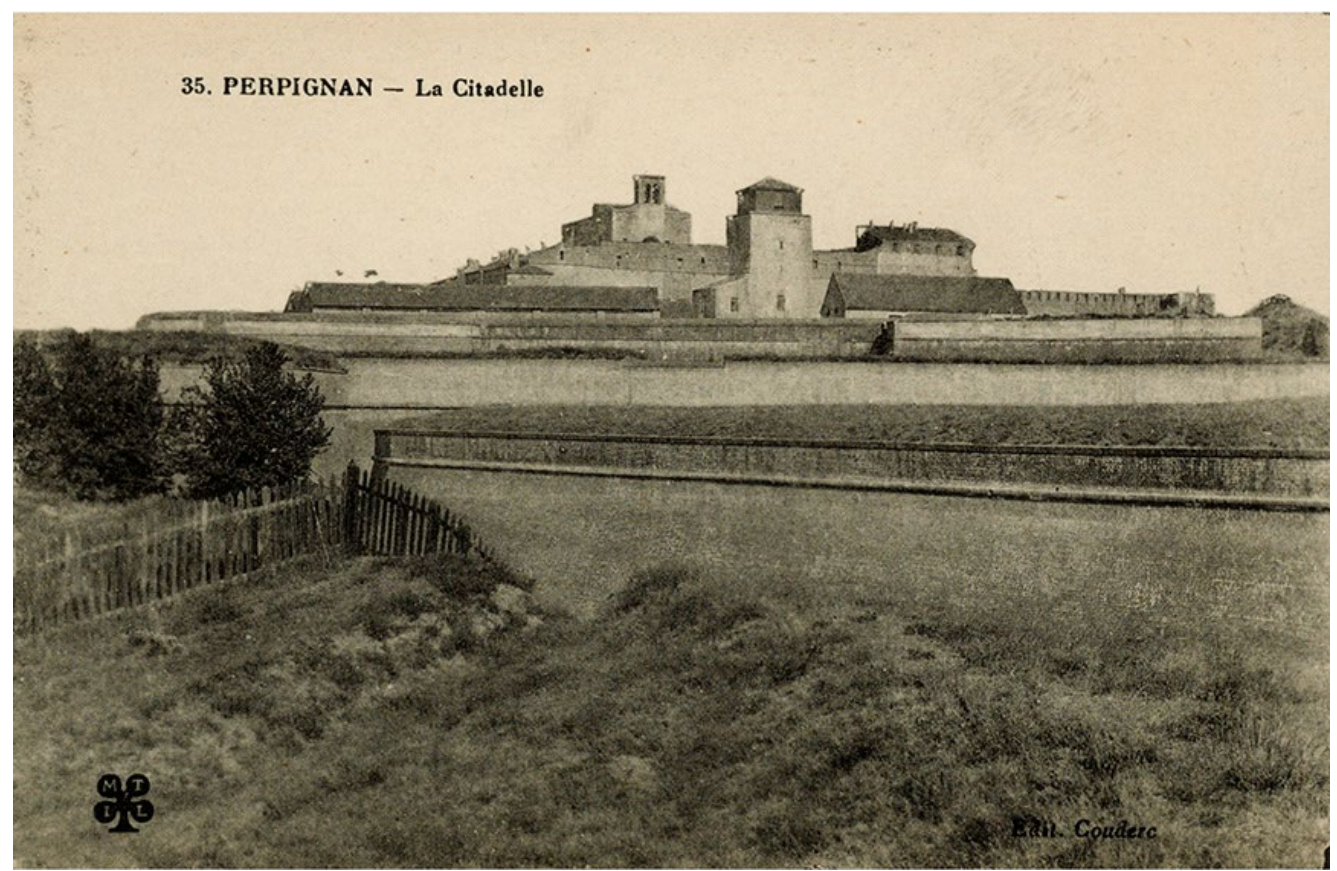

French walled medieval cities, such as Avignon, Perpignan, or Vendome, anchored to the earth, with their sharp silhouettes standing out against the landscape (Figure 7-8) or this other one capturing the urban contours of ancient Paris (Figure 9) are accompanied by sketches such as this one of an unknown building, precisely taken at sunset (Figure 10). Coupled with another double postcard depicting the lines of the Alhambra Palace against the mountains, they all remind us of the abundant urban analysis he made during his trip to the East in 1911 (Figure 11). They form a long iconographic suite that finds its continuation in his sketches of the bombed chapel of Ronchamp at the top of the Bourlement hill. Made in 1950 as he approached the site on the train, they help to understand Le Corbusier's words when talking about the key inspiration behind the project: "We create forms to meet these horizons, to accommodate them" (Le Corbusier, 1952, p. 72)'. This new urban scale for the $20^{\text {th }}$ Century will culminate 


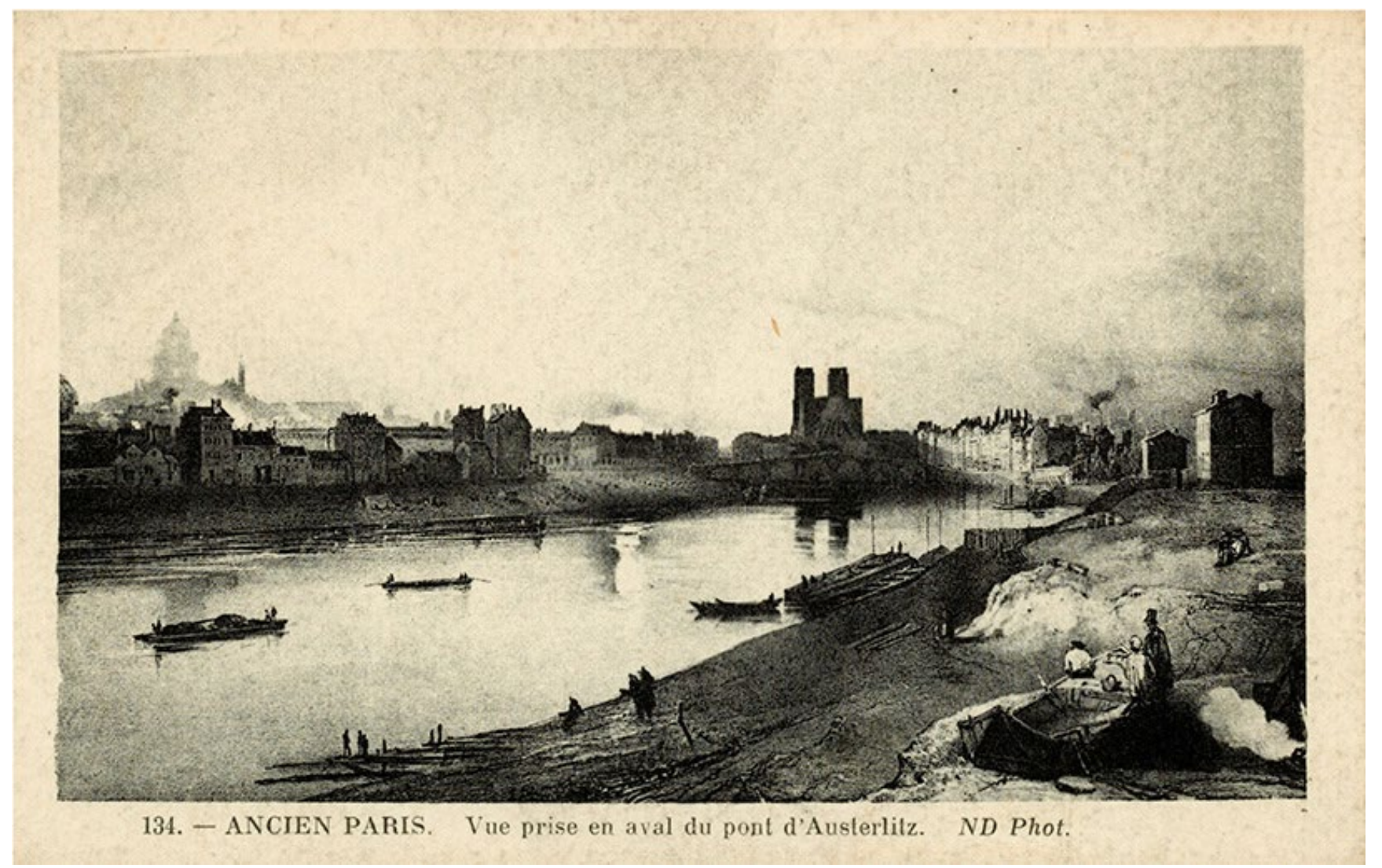

Figure 9. Old Paris, view downstream from the bridge of Austerlitz, Paris (France), postcard, n.d.

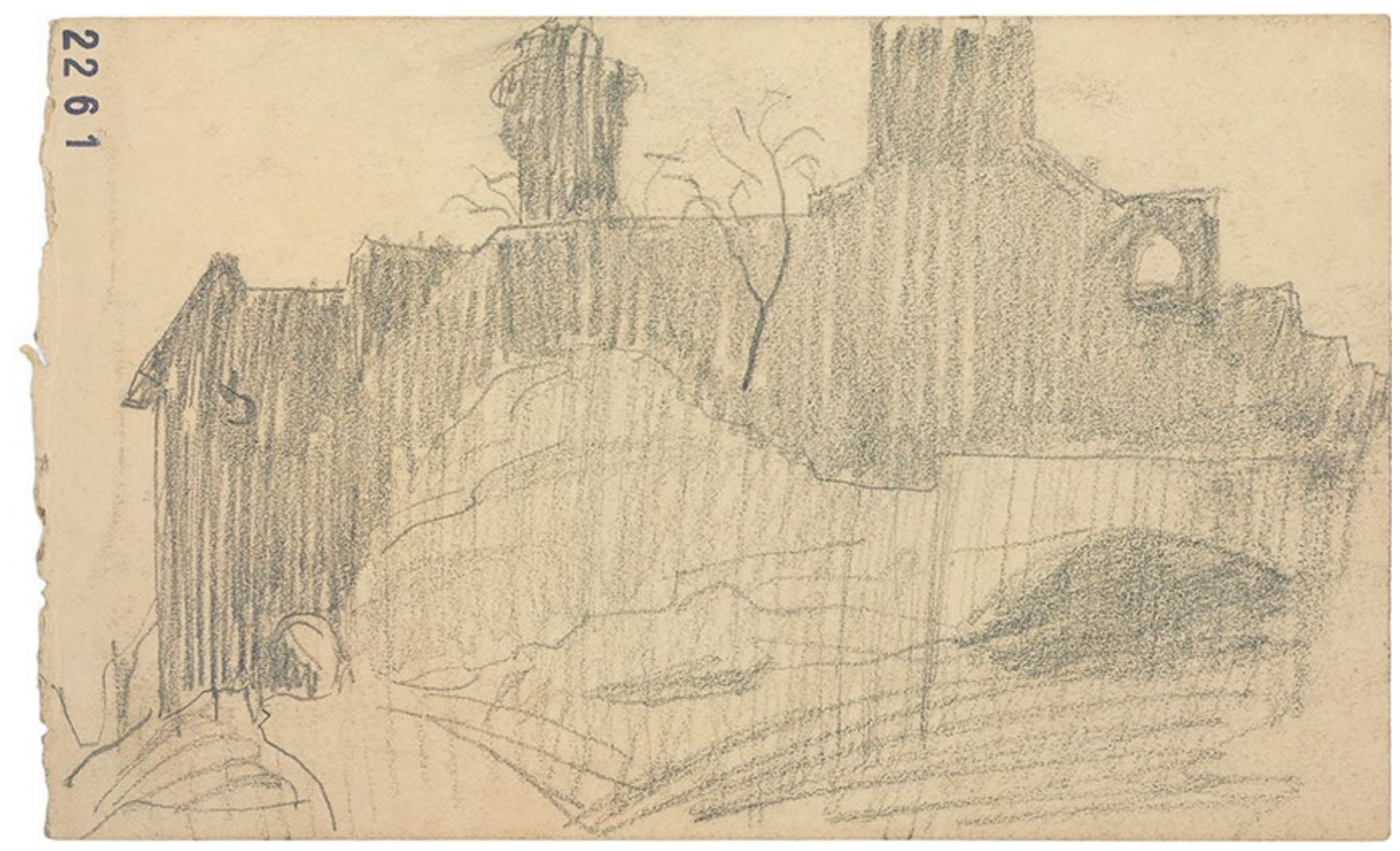

Figure 10. City walls, n.d., pencil on paper 


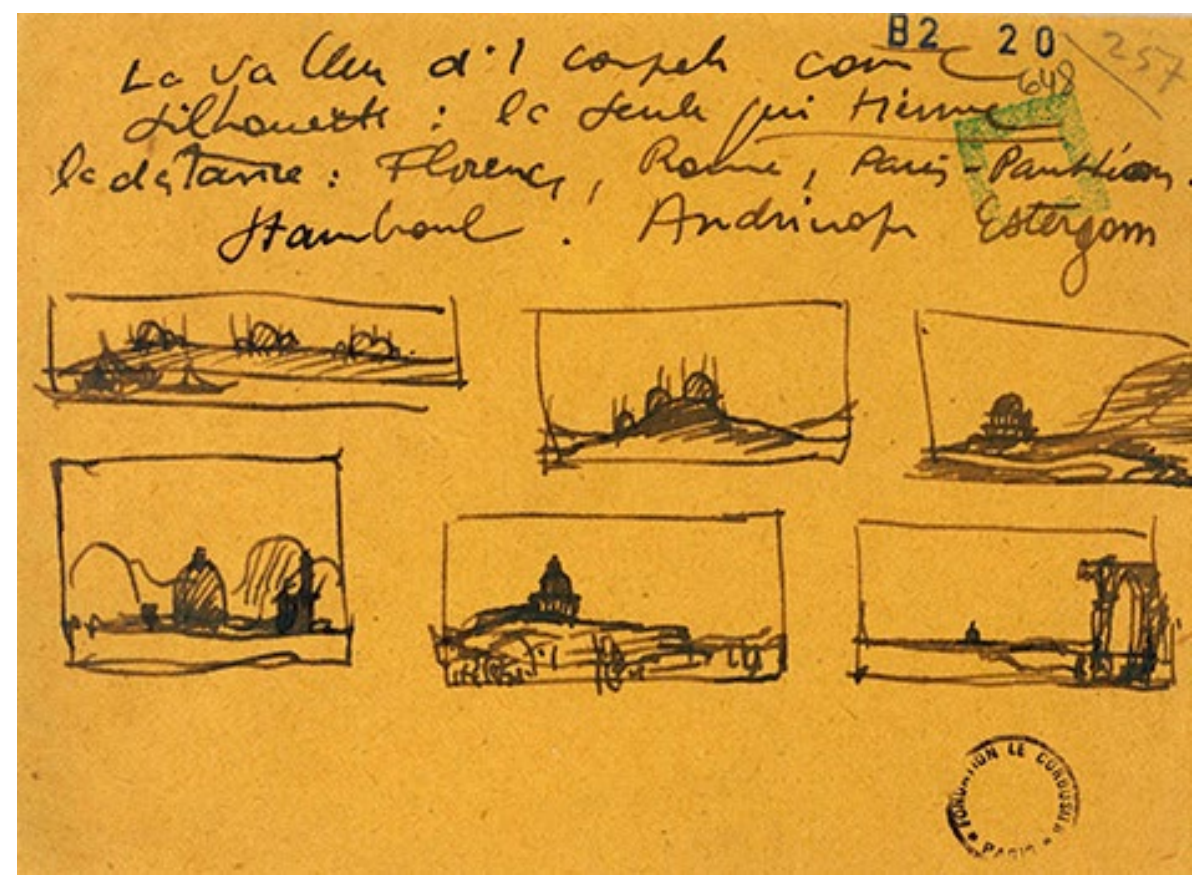

Figure 11. Urban silhouettes, around 1911, ink on paper, later published in Le Corbusier \& $P$. Jeanneret: Frvre complète, 1910-1929 (Le Corbusier, 1937)

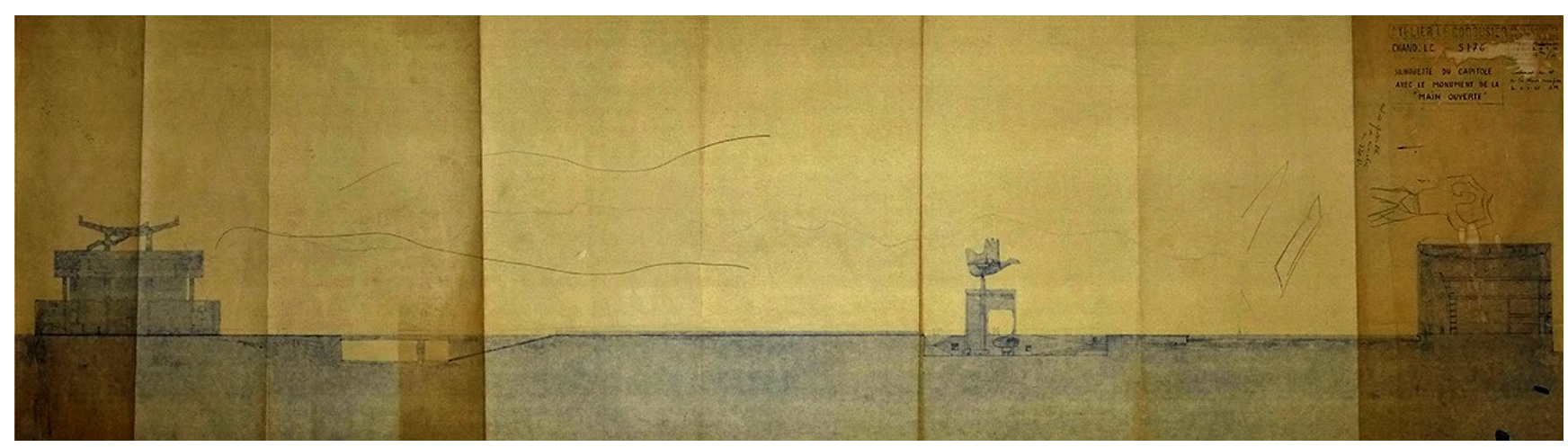

Figure 12. Silhouette of the Capitol complex with the Open Hand, Chandigarh (India), Plan CHAND. L.C. 5176, January $3^{\text {rd }} 1955$, ink and pencil on paper

with the introduction of a new landscape composed through silhouettes, an idea which governs the position and relations between the different buildings of the Capitol complex in Chandigarh (Figure 12) $)^{2}$.

His capacity to freely manipulate subjects out of their original context allows him to re-interpret and re-invigorate elements infused by a sculptural potential, aside from their original function and scale. Thus, they can be transferred to play un unexpected role in completely different conditions, and in this transmutation, give rise to a new architectural solution. A noteworthy case present in the collection is the postcard titled "Airship Hangar. Training area at Issy-les-Moulineaux" (Figure 13). First of all, it has been used as an illustration in the text "Formation of modern optics" of Le Corbusier's book La peinture moderne (Le Corbusier, 1925, p. 66). However, it is fascinating to compare it with the entrance canopy covering the path leading to the Villa Ternisien, built a year later (Figure 14), a pergola, in fact a filter endorsed with the same intangible and light qualities, but on a reduced scale.

Surprisingly enough, it recovers the typology already captured by Le Corbusier in his notes taken in 1917 when studying the book Hypnerotomachia Poliphili (Figure 15) ${ }^{3}$, kept at the French National Library. We can travel further on and say that the virtues 


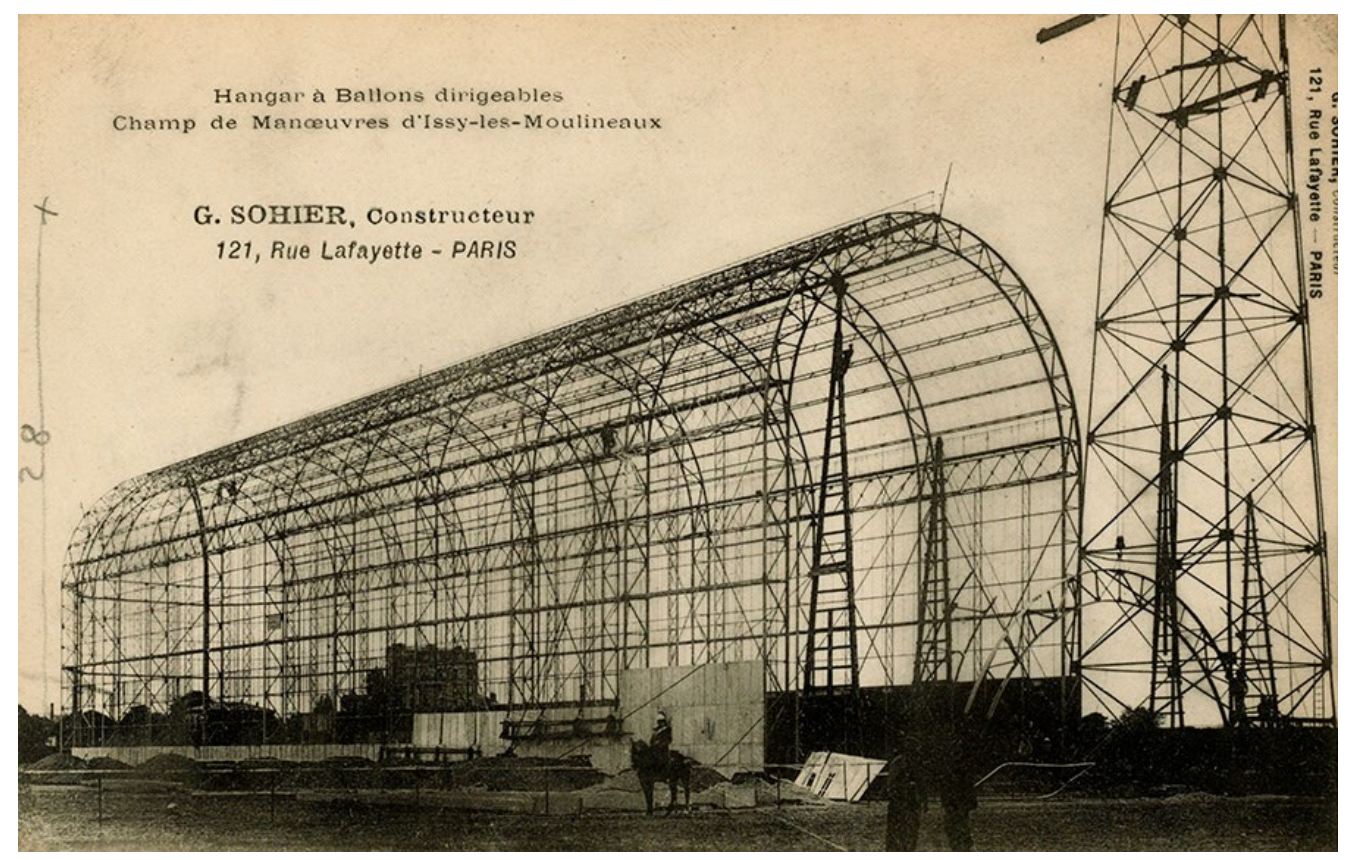

Figure 13. Airship hangar. Training area at Issy-les-Moulineaux (France), postcard, n.d.

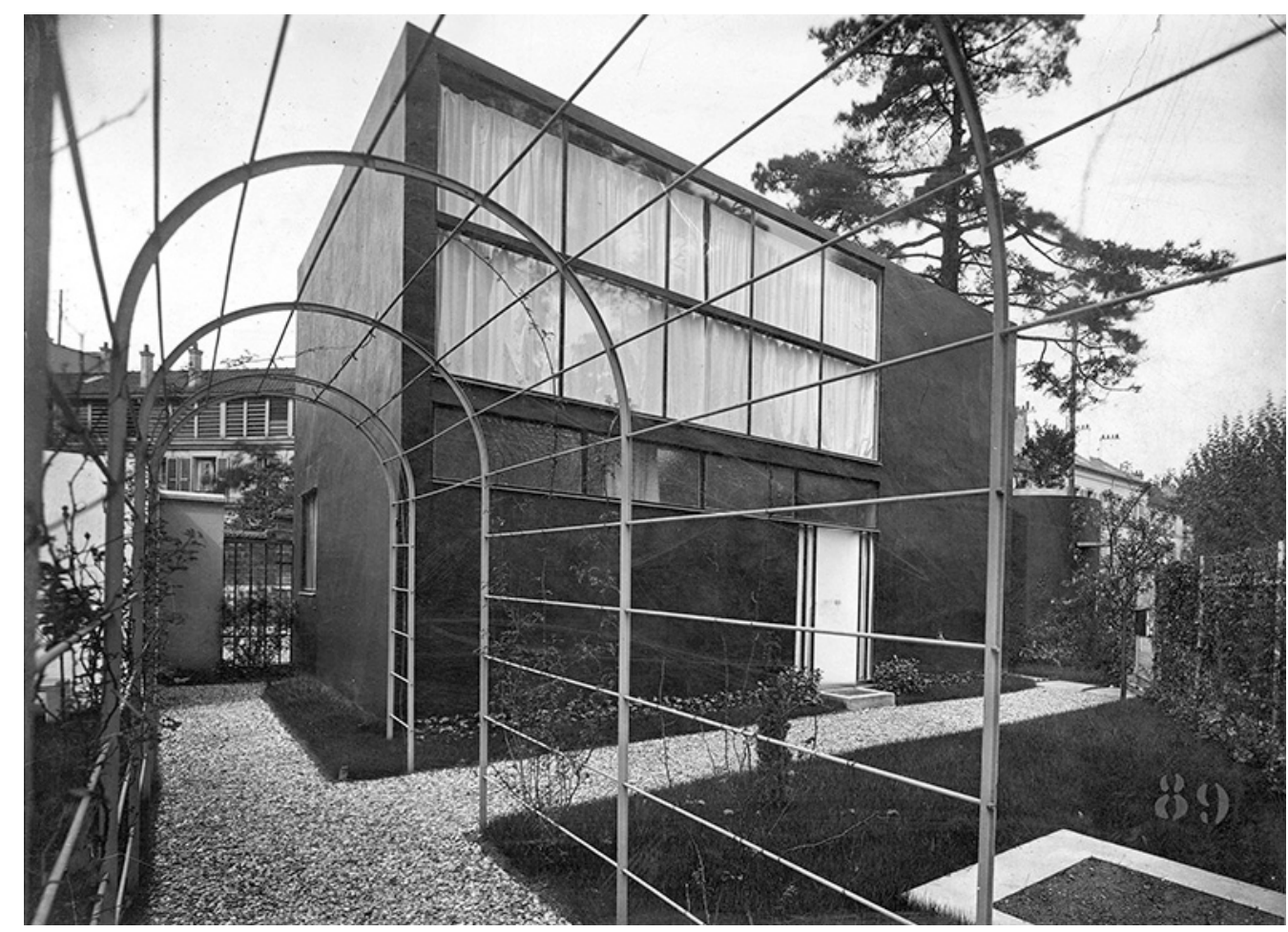

Figure 14. Entry canopy for the Villa Ternisien, Paris (France), 1926, photo

of a highly industrialized, modular and removable building constitute the germ of the project for the temporary Pavilion des Temps Nouveaux from 1937 (Figure 16), especially after reading his description of the project: "its section clearly shows the clean separation between the container (the tent) and the content (ramps and demonstration booths)" (Le Corbusier, 1938, p. 160) 4 . 


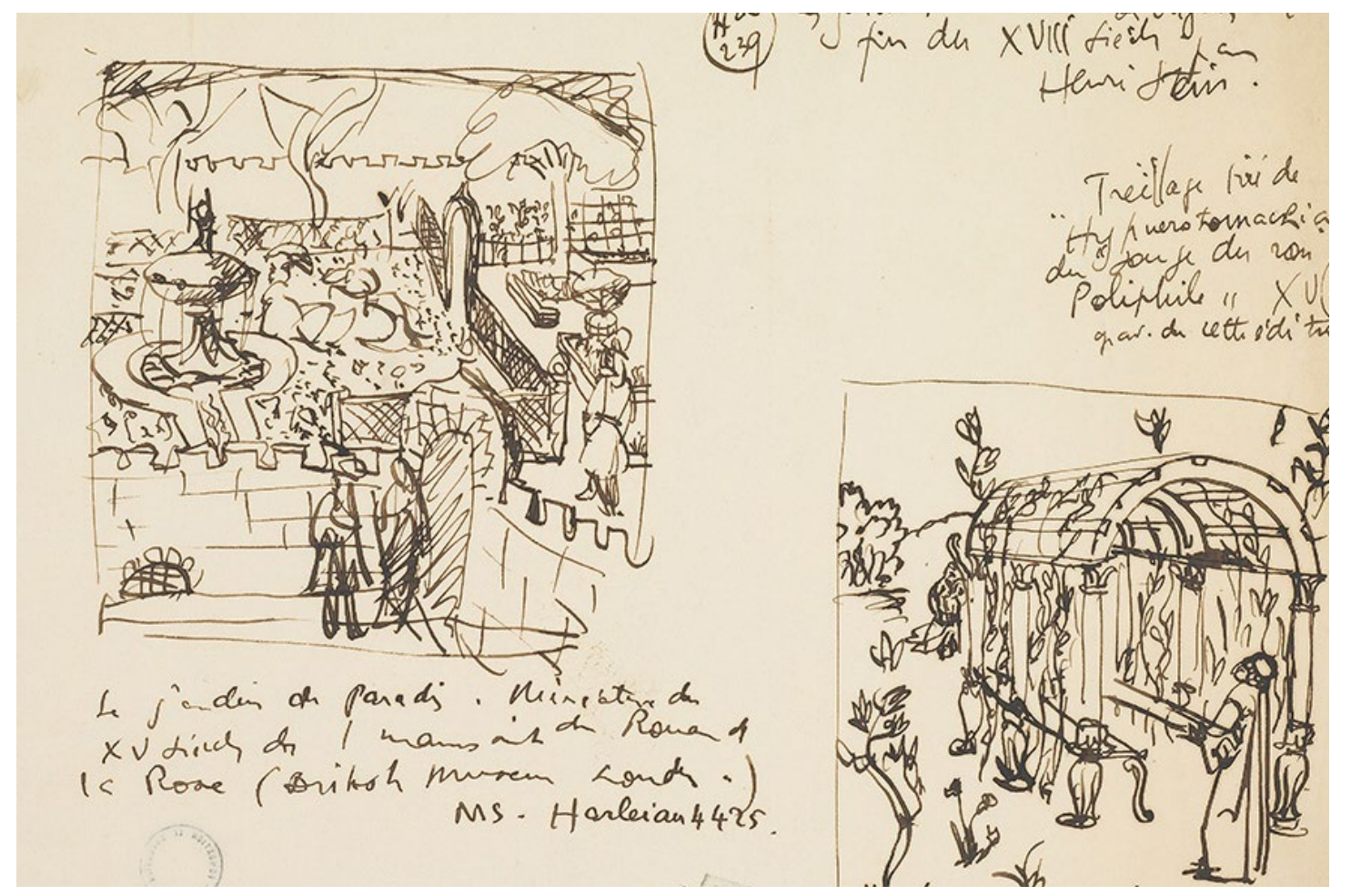

Figure 15. Garden, 1915, ink on paper, drawing by Le Corbusier done while studying at the National Library of France after original illustration found in Hypnerotomachia Poliphili (Colonna 1499)



Figure 16. Metal framework for the Pavilion des Temps Nouveaux during construction, Paris (France), 1936, photo 


\section{EDUCATION TO UNDERSTAND THE WORLD AROUND HIM, TO INCORPORATE THE TRADITION}

The collection reveals another facet of his insatiable curiosity in addition to alternative data collecting sources, such as his sketchbooks or his photographs. It was conceived as a living archive nourished throughout his entire life, serving as a checklist to fix places, subjects and compositions which have been experienced in first person. This last issue is very important, because these images are thus charged with sensorial memory and meaning. They participate within a major iconographic network that brings together different materials. While visiting the Museum of Decorative Arts to study the dimensions, proportions and design of its magnificent furniture collection, postcards will perform their role as a physical support to write down measurements and sketches (Figure 17).

In his Voyage to the East of 1911, postcards were a common means to drive a constant exchange with his parents but many others remained unwritten, giving birth to a collection which will eventually become a testament to his interests. As we see in relation to the Parthenon, his own sketches reflect a specific subject already depicted in a few postcards. ${ }^{5}$ These pieces will also allow him to return later to accurately analyze details he might have missed during his visit, thus helping to finish and complete the drawings.
Most important is the use of multiple sources based on the same subject to offer different perspectives ranging from the touristic, objective and almost banal to his subjective and personal perception. Thus, the Pantheon becomes deeply attached to his experience through three different media: a postcard, a comment in his notebook and a photograph. The first medium (Figure 18) offers a general point of view from which we can gather an overall image of the inner world, the effect of the light shaft in the space, the scale, further details and composition of the façades and historical data able to help the young Jeanneret to frame the evolution of roman architecture. His sketch (Figure 19) firmly traces down the real proportions of the dome strongly distorted because of the perspective effect, in fact, correcting the visual deformation also portrayed in the original engraving (stretched to fit the given space). General fenestration is lightly indicated as he can get back to the postcard in order to capture details more faithfully. Finally, his own photo (Figure 20), looking upwards, tries to capture the most difficult part of the experience lived in situ: the atmosphere, the genius loci. Due to technical reasons, the camera has a quite limited range of view, but that allows Le Corbusier to focus on the most important feature, dramatically enhanced by the encasings of the dome.

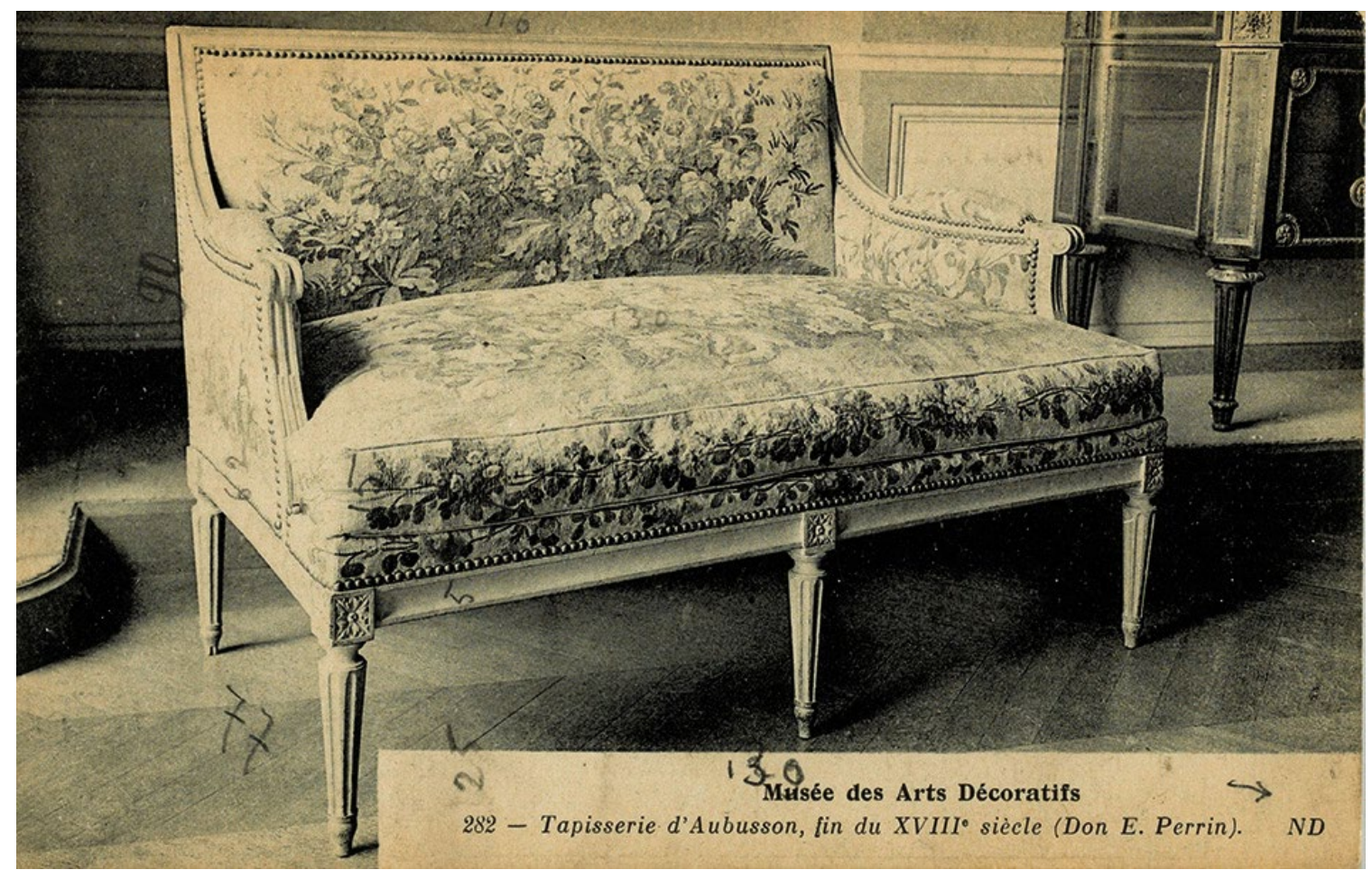

Figure 17. Upholstery fabric from Aubusson, late XVIIIth century, Museum of Decorative Arts, postcard, n.d. 


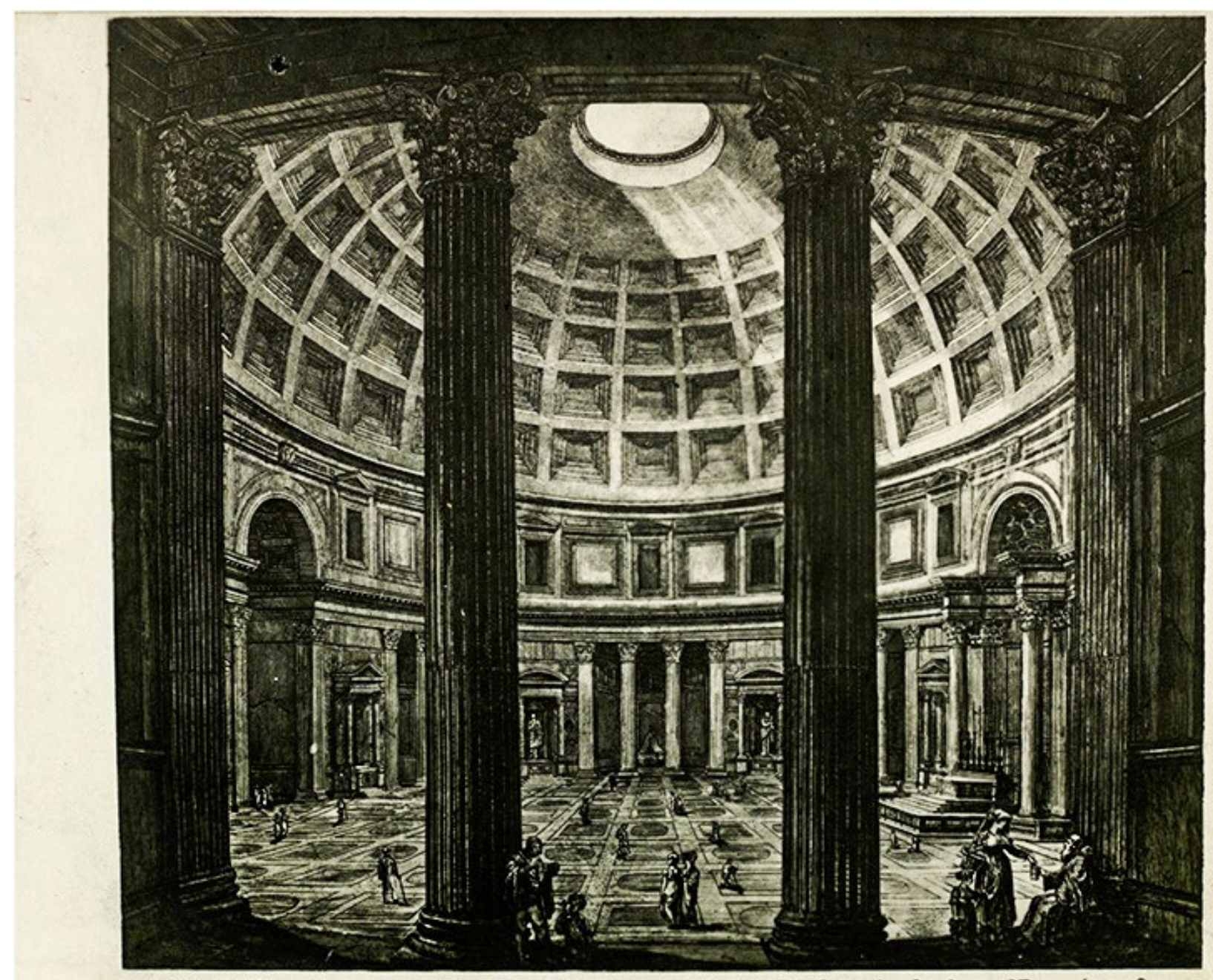

28I. ROMA - Pantheon d'Agrippa - Interno - edificato dal Console Agrippa 27 anni a. C.

Figure 18. The Pantheon, Rome (Italy), postcard, n.d.

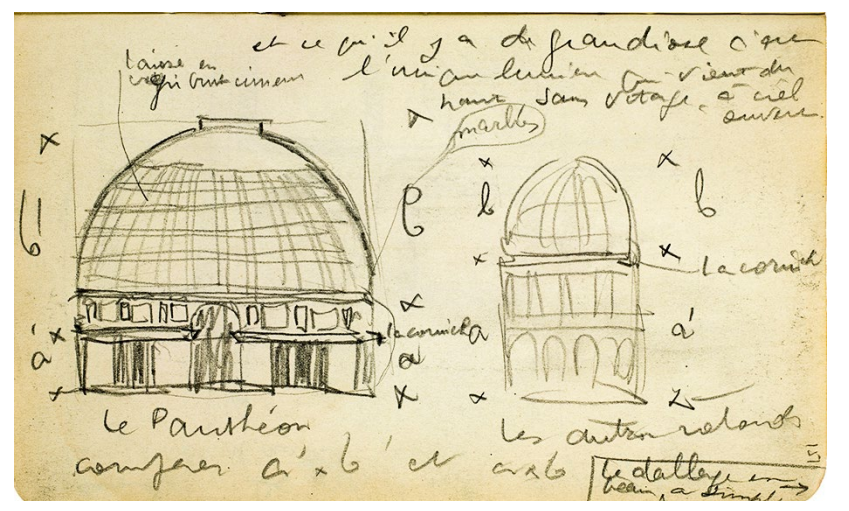

Figure 19. Section of the Pantheon, Rome (Italy), around 1911, pencil on paper, drawing by Le Corbusier taken from his sketchbook $\mathrm{n}^{\circ} 4$ during his Voyage to the East

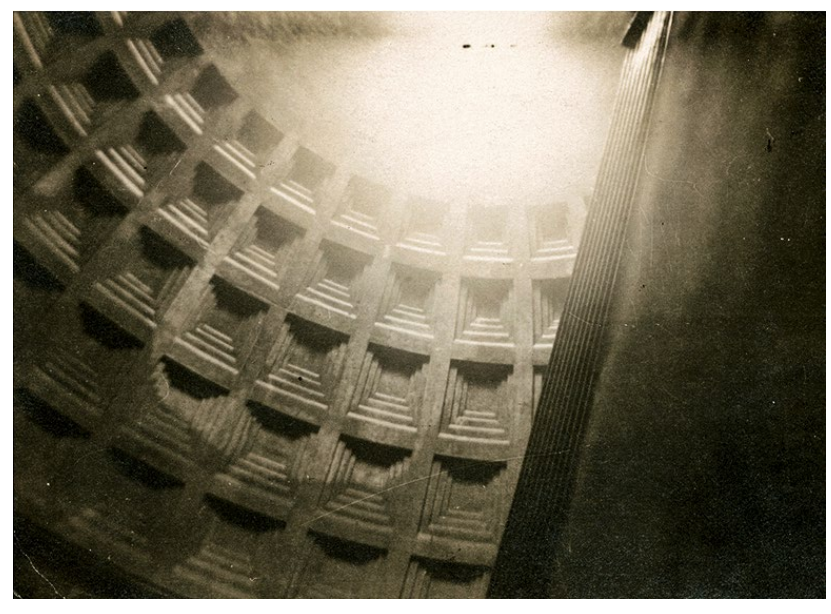

Figure 20. Interior view of the Pantheon, Rome (Italy), around 1911, photograph by Le Corbusier, later published in Vers une Architecture (Le Corbusier, 1923) 
While studying at the Library of Sainte Geneviève in 1907, his annotations on the mosque of Cordoba (Figure 21) will be later extended with this postcard (Figure 22). The pencil marks re-frame the specific area of the image to be incorporated in his book La Ville Radieuse (Le Corbusier, 1935, p. 136), but on the back, he also writes down a few comments that allow him to reflect upon the lessons he has learned: "The vertical glorifies the horizontal. In Girona, Tarragona, Seville, Cordoba; everywhere architecture is fully appreciated on foot, it is a true promenade" 6 ; an argument which will find an echo with other postcards from Algiers. ${ }^{7}$ As we just said, these images are fully charged with emotions

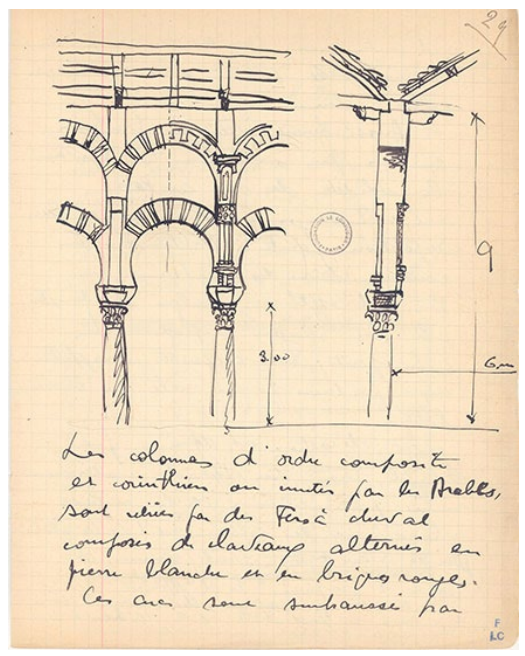

Figure 21. Detail from arcades of the Mosque-Cathedral of Cordoba (Spain), 1908, ink on paper, drawing by Le Corbusier done while studying at the Library of SainteGeneviève after original illustration found at Corroyer (1888)

Figure 22. MosqueCathedral of Cordoba (Spain), postcard, n.d. because they were bought directly on site, right after his visit and not simply found in a book. This is a crucial aspect which allows him to re-encounter, revive and refresh this same spatial experience 25 years later in a completely different setting. The notes found in this page from his sketchbook made in June 1955 (Figure 23) are revealing: “A groove of trees sharply cut at the height of a cow = creates a large area under stilts / all of a sudden, mosque of Cordoba".

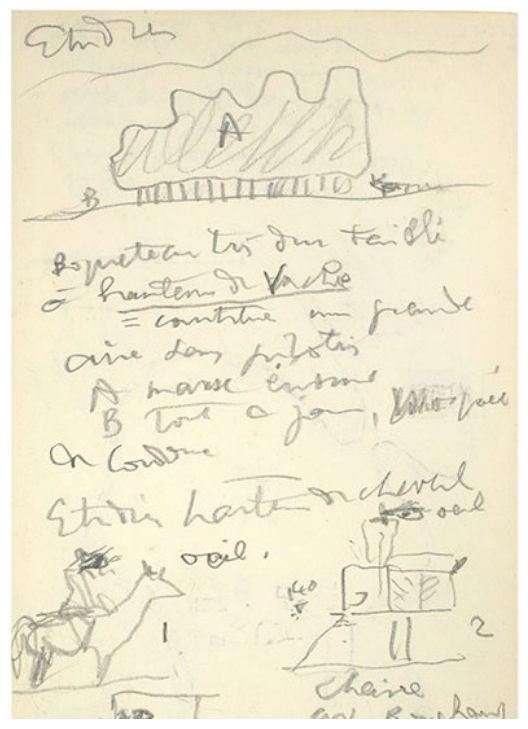

Figure 23. A small mass of trees, June 1955, pencil on paper, drawing by Le Corbusier taken from his sketchbook K41 


\section{RATIFICATION AND AUTHENTICATION OF HIS} RESEARCH UNDER THE LIGHT OF ANCIENT MODELS

As specified in the first part of this text, stability and transition are the core terms within his architecture. Le Corbusier's works not only want to propose a valuable solution for the modern man but also strive to become charged with the evocative power of the past, to become part of tradition. While visiting Bogotá in May 1951, he records the well-known Plaza del Toro, about which he will say (Figure 24): “The Plaza del Toro // confirmation of the $200 \mathrm{~m}$ wide rings for the Saint-Baume." 8 Therefore, he is delighted to uncover a clear relation between this building and his first plans for the residential complex accompanying the design for the Basilica. The typology of a circular arrangement of apartments

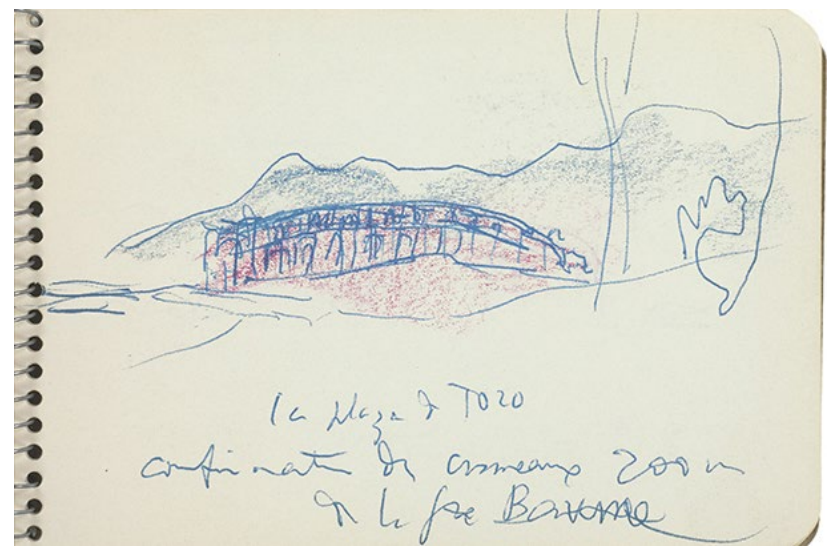

Figure 24. Bull ring, Bogota (Colombia), February 1950, colored pencil on paper, drawing by Le Corbusier taken from his sketchbook D16

Figure 25. Amphitheater, Arles (France), postcard, n.d.

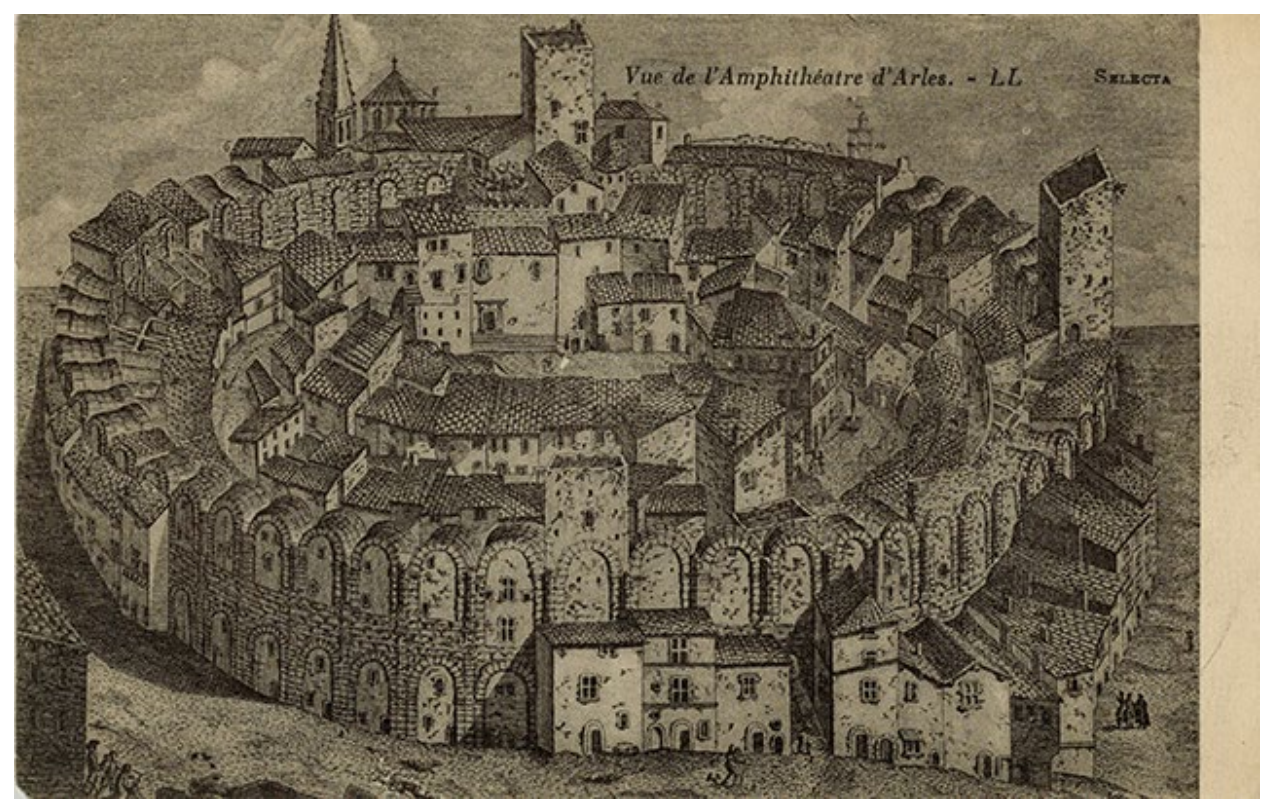

in the form of a thick wall was certainly common in some European countries, where at the fall of the Roman Empire, the former circus was occupied and retrofitted with a residential program. The architect does in fact keep a great example in his postcard collection: the old Arena of Arles (Figure 25). As we see, closely related and sometimes inextricably blended with the second goal, this process is not exclusively related to postcards, as the clearest examples are found in his sketchbooks. A few days later, on May $12^{\text {th }} 1951$, a new connection with another of his past projects appears when regarding the silhouette of a brick kiln (Figure 26): “I discover this brick kiln at the top of the clearing of a hill eight days after having sent to Simla the project for the Capitol (Governor's Palace) and I find here an extraordinary confirmation." 9

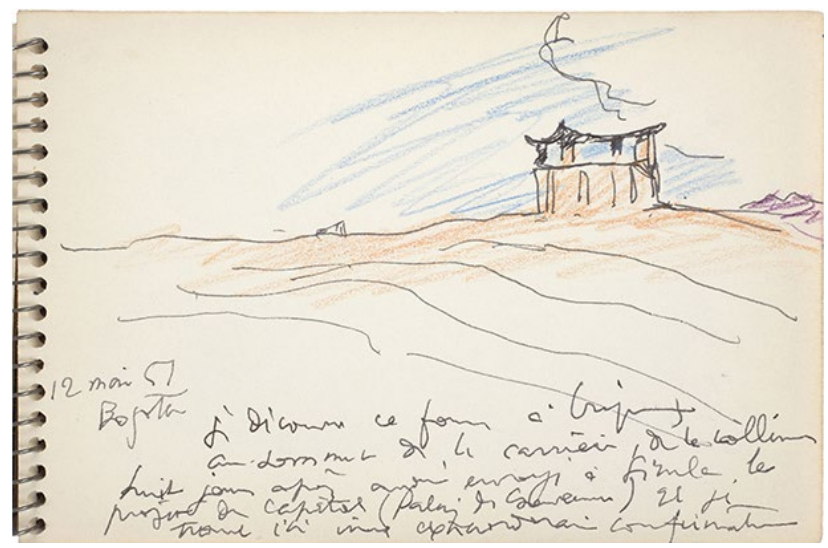

Figure 26. Brick kiln, Bogota (Colombia), May $12^{\text {th }} 1957$, colored pencil on paper, drawing by Le Corbusier taken from his sketchbook E20 


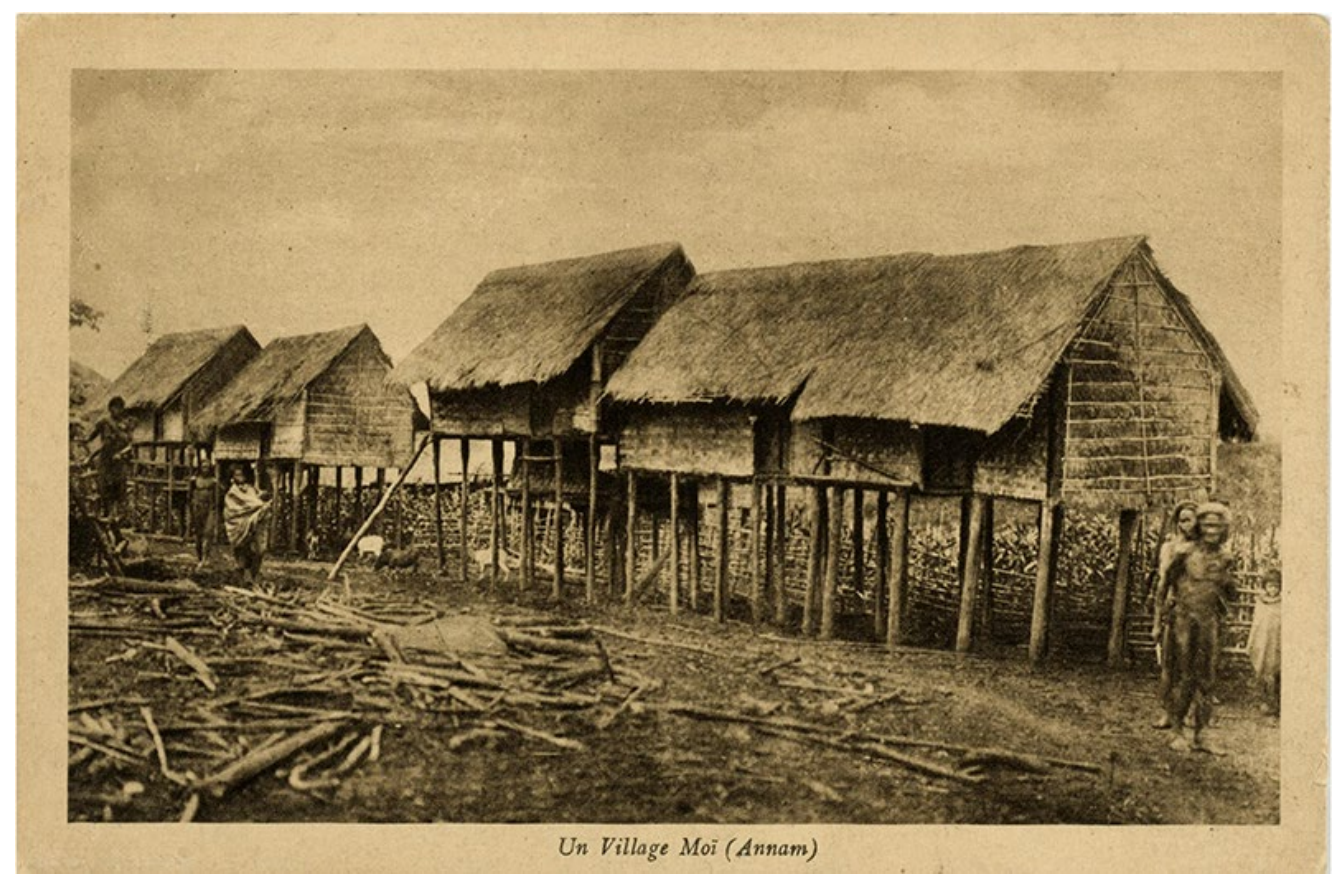

Figure 27. A Moï village, Annam (Vietnam), postcard, n.d.

Figure 28. Peasant house, Esbly (France), July $7^{\text {th }} 1932$, pencil on paper, drawing by Le Corbusier taken from his sketchbook B6

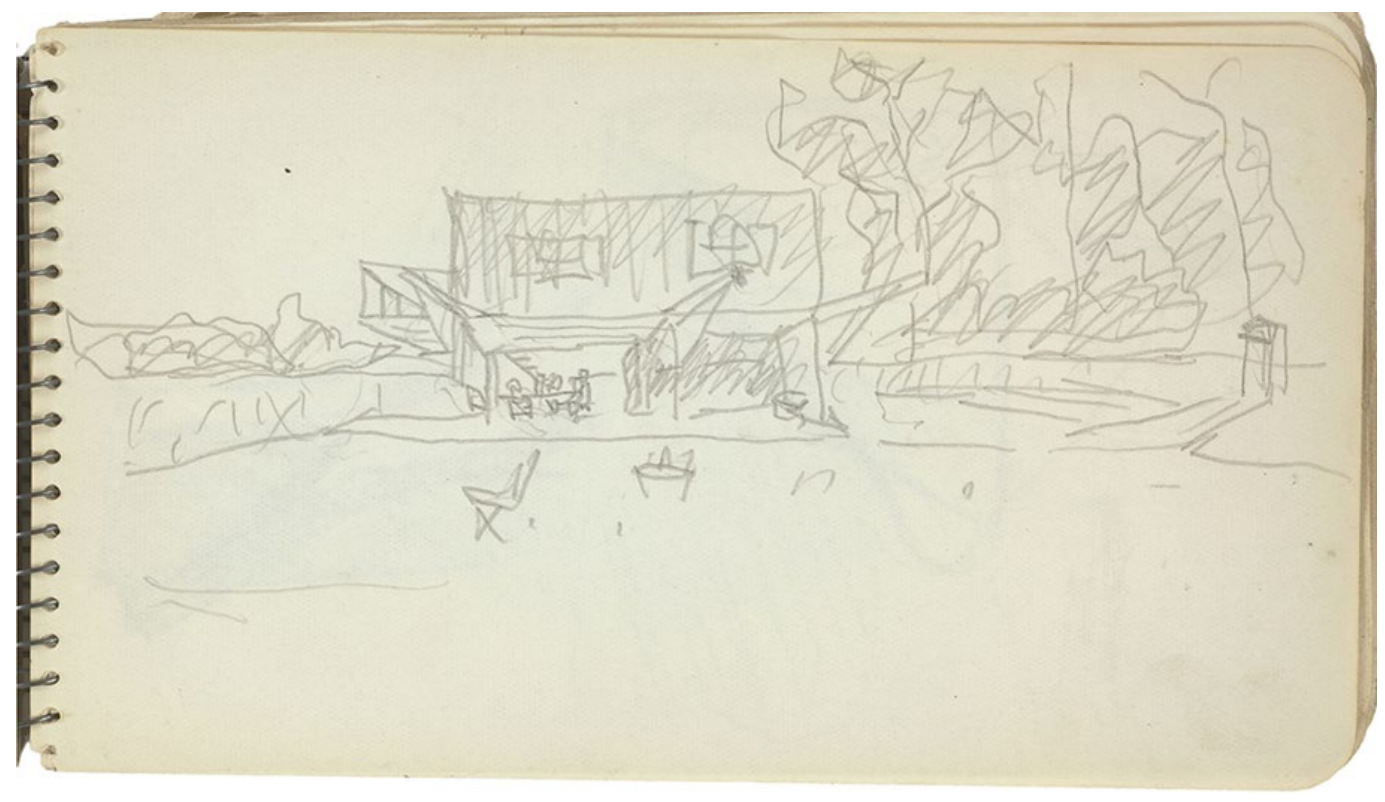

Following the same idea, peasant houses lifted on pilotis are the subject of two different postcards, one portraying the Moï villa of Annam (a former French colony in Vietnam) and another from Cambodia (Figure 27). Both are closely related to the summer houses that Le Corbusier visits in Esbly on July $10^{\text {th }}, 1932$ (Figure 28). These sketches along with a few pictures are also included in his book La Ville Radieuse, where we read: "During five months, life is carried out under the pilotis, lunch, dinner, cooking, making the food, etc., welcome of guests" (Le Corbusier, 1935, p. 29). These findings reassure Le Corbusier about his own approaches, since in this way, projects designed and conceived at very different times and locations find a common conceptual line, thus infusing his works with the timeless significance of past civilizations. Good architecture is about revealing its own capacity to evoke, to embrace and to enclose the tradition.

The inhabited elevated highways he designed in 1929 to conquer the wild nature surrounding the city of Rio de Janeiro (Figure 29), can be inspired or in turn, rediscovered in these series of postcards from Morlaix or Gorges du Loup (Figure 30): the image of the the bridge as a manmade landscape becomes a recurrent subject for the architect. In 1928, on page three of Une maison, un palais, he will propose a 


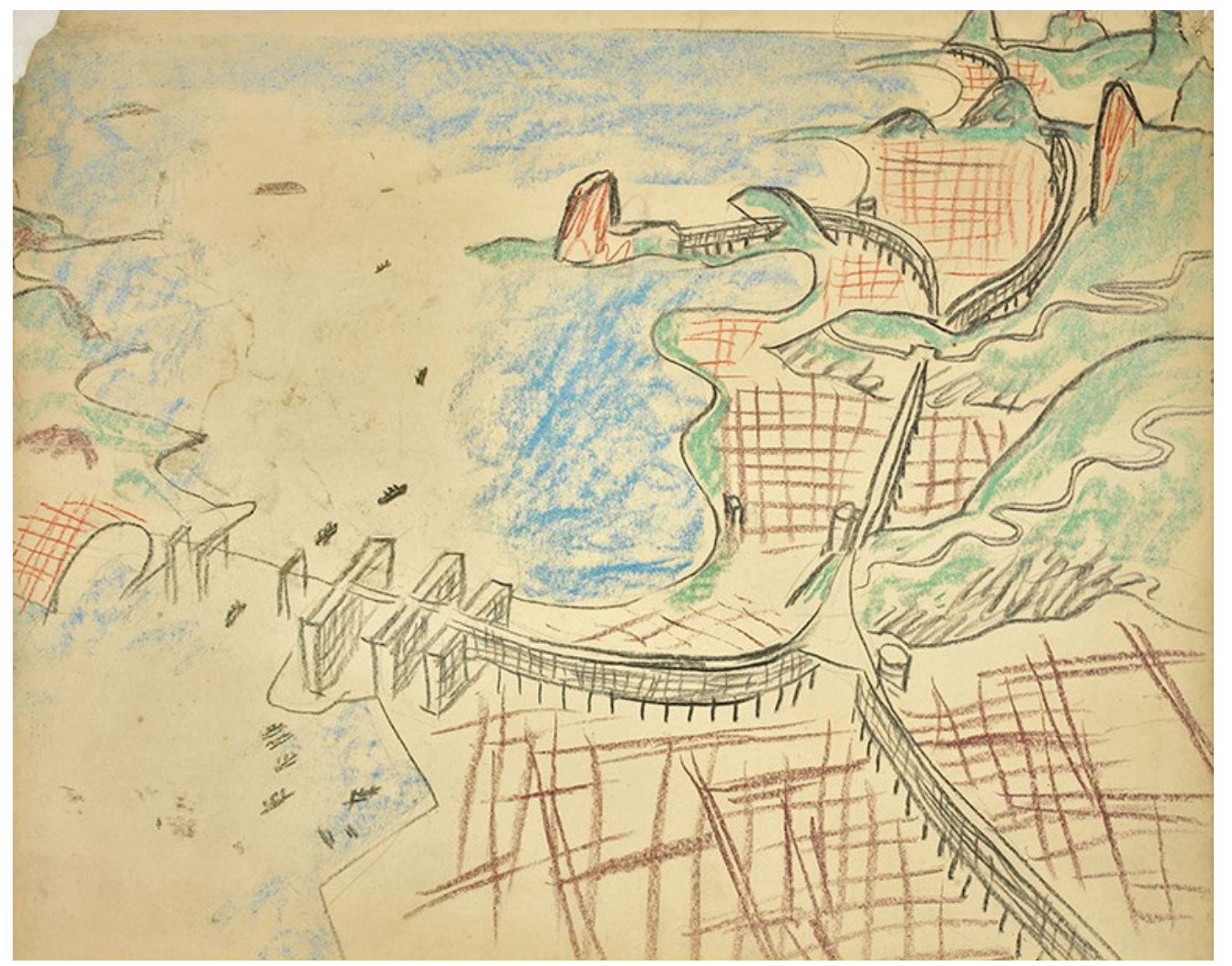

Figure 29. Perspective, urban planning proposal for Rio de Janeiro (Brazil), 1929, colored pencil on paper, later published on Le Corbusier Précisions, Paris: Crès, 1930

Figure 30. The viaduct, Gorges du Loup (France), postcard, n.d.

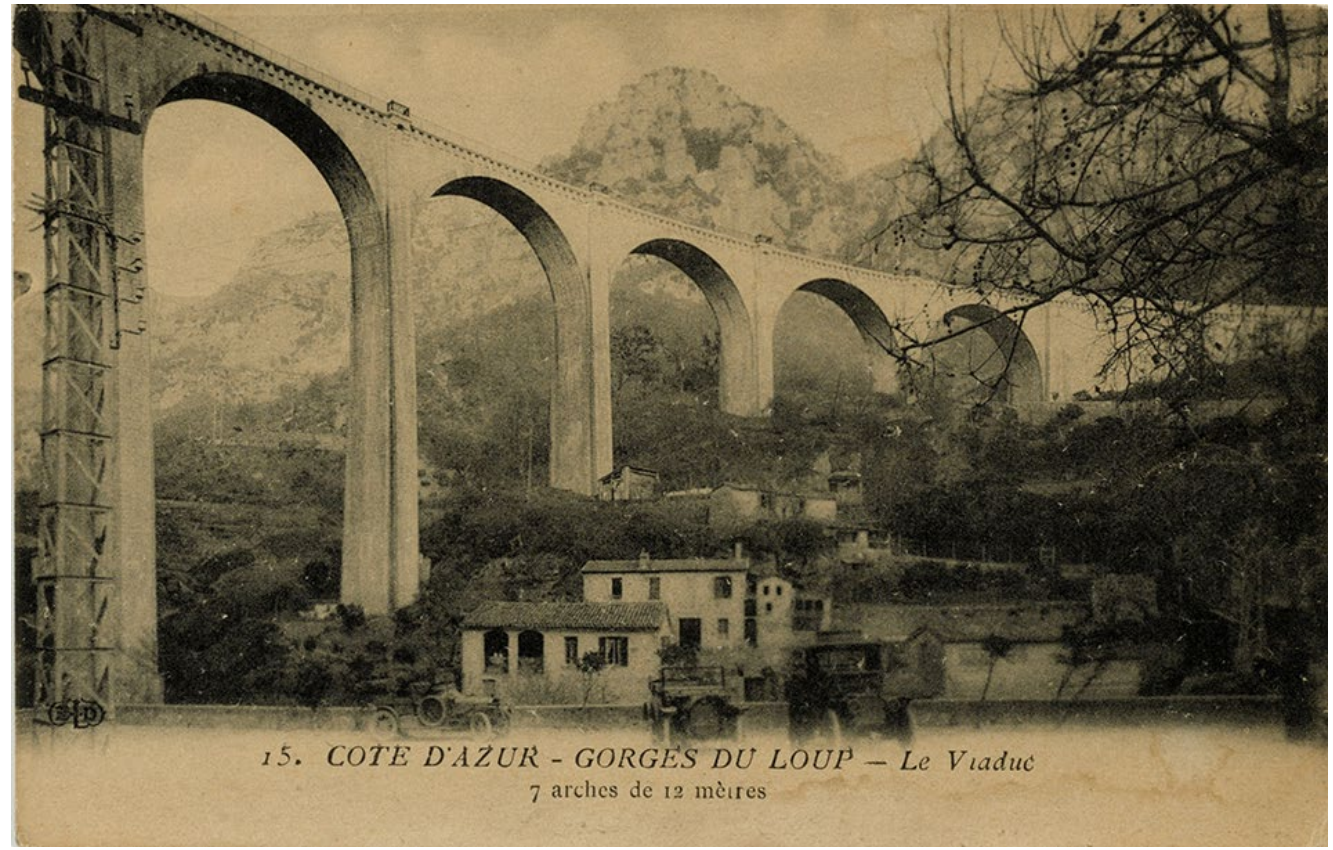

question: "why are bridges so moving?", to which he will answer: "because in the apparent inconsistency of nature and in the clear dissonance of contemporary cities, a bridge is a place of geometry and geometry is clear as day, unambiguous, and the bridge is an act of will, and geometric will is an act of optimism" (Le Corbusier, 1928, p. 3) $)^{16}$. Of course, given the lack of information and the impossibility to determine the date for the acquisition of certain pieces (mostly those related to his home country), sometimes it is especially difficult to establish the chronological sequence of events, and so we might be fluctuating between inspiration or ratification. 


\section{CONCLUSION}

Up until now, these postcards had remained almost forgotten, given a secondary role. The scientific value of this paper relies in the fact that it helps to cast light upon a source, which combined with other mediums such as photography, drawing, painting, writing or newspaper clippings, presents a rich kaleidoscope of means able to offer Le Corbusier a multi-layered and associative analysis. Grouping theses postcards in an appropriate arrangement uncovers the notion of Poetical assemblage, which fully relies on connectivity, identity and coherence. Poetical assemblage is the key to reveal the associative inner force embedded in this material, at first, devoid of any meaning. It proves that this collection deserves to have the same value as any other research tool. His creative process is deeply attached to close and distant context: recording, understanding, decoding and manipulating so as to develop a distinct conception. His architecture, in this way, becomes both fully immersed within tradition and fully responding to modern times.

\section{FIGURES}

All credits Fondation Le Corbusier, except otherwise stated. All postcards from Le Corbusier's postcard collection.

\section{NOTES}

1. Among others works: Catalogue of the 1988 exhibition Le Corbusier, le passé à réaction poétique (Le Corbusier \&al, 1988); Viaggio in oriente (Gresleri, 1984); Le Corbusier's Formative Years (Brooks, 1997); Le Corbusier, the Noble Savage. Towards an Archaeology of Modernism (Vogt, 1998); Le Corbusier before Le Corbusier (Von Moos, 2002).

2. Only twice will he give us a hint of his interest and both nearly at the end of his life. First in a letter written on March $2^{\text {nd }} 1959$ to his collaborator Guillermo Jullian de la Fuente. After seeing Guillermo's sketches from some of the most well-known monuments in Venice, Le Corbusier will ask him if he had made them from scratch or if he had copied them after a set of given postcards. Second, an annotation made in 1963 in his sketchbook. After visiting the Gallerie dell'Accademia in Venice, he will jot down the need to ask for a postcard of the painting Martyrdom of the Pilgrims and the Funeral of St Ursula by Vittore Carpaccio, (Sketchbook T70).

3. In fact, it should be noted that some of the postcards he sent were repeated as blanks in his collection, clearly pointing out which ones had an important meaning apart from the sentimental power related to people he was corresponding with.

4. All English translations are by the author unless otherwise noted. A few pages later, he will also underline: "Deans of Faculties and their advisors do not understand that synthetic souls are as essential as analytic souls". The original passage reads: "Les savants de génie, outre le pouvoir d'observer et de comprendre, possèdent d'autres qualités, l'intuition, l'imagination créatrice. Par l'intuition, ils saisissent ce qui est caché aux autres hommes, ils perçoivent des relations entre des phénomènes en apparence isolés, ils devinent l'existence du trésor ignoré".

5. Along with his friend Auguste Klipstein, he started this crucial trip on May 1911 departing from Dresden and passing through Prague, Vienna, Budapest, Belgrade, Bucharest, Tarnovo, Gabrovo, Kazanluk, Istanbul, Mount Athos, Athens, and Italy.

6. The original passage reads: "La technique des groupements est en quelque sorte une manifestation de la sensibilité moderne dans la considération du passé, de l'exotisme ou du présent. Reconnaître les "séries", créer à travers temps et espace des "unités", rendre palpitante la vue des choses où l'homme a inscrit sa présence".

7. The original passage reads: “0n créa des formes pour répondre à ces horizons, pour les accueillir".

8. This notion of urban landscape composed by the profile of buildings against the backdrop of the mountains is confirmed by his former collaborator Balkrishna Doshi in Le Corbusier and Louis I. Kahn, the Acrobat and the Yogi of Architecture (Doshi, n.d.).

9. The book traces Poliphilo's dreams while pursuing his love Polia. Le Corbusier copied some illustrations showing architectural settings where the adventures of the main character take place.

10. The original passage reads: "la coupe montre clairement la séparation nette entre le contenant (la tente) et le contenu (les rampes et les stands de démonstration".

11. Some drawings offer exactly the same views already captured in postcards, which surely explains the question he once addressed to Guillermo de la Fuente (see note 2). 
12. Postcard L5-4-167. The original passage reads: “La verticale exalte l'horizontale. Partout, Gérone, Tarragone, Sevilla, Cordoue, l'architecture s'apprécie à la marche, c'est une promenade".

\section{See FLC L5-03-061 and L5-03-062.}

14. Le Corbusier Sketchbooks, FLC W1-2-171. The original passage reads: “ La Plaza del Toro // confirmation des anneaux $200 \mathrm{~m}$ de la Ste Baume". La Sainte-Baume was an ambitious project from 1948. It proposed a religious complex comprising a pilgrimage residence along with a Cathedral hollowed out in the rock.

15. Le Corbusier Sketchbooks, FLC W1-2-431: “Je découvre ce four à briques au sommet de la clairière, de la colline huit jours après avoir envoyé à Simla le projet du Capitole (Palais du Gouverneur) et je trouve ici une extraordinaire confirmation".

16. The original passage reads: "parce que dans I'incohérence apparente de la nature et dans celle effective des villes des hommes, un pont est un lieu de géométrie et la géométrie est une chose claire, sans ambigüité, et le pont est un acte de volonté, et la volonté géométrique est un geste d'optimisme".

\section{REFERENCES}

Brooks, H. Allen. (1997). Le Corbusier's formative years. Chicago and London: University of Chicago Press.

Carrel, Alexis. (1936). L'homme, cet inconnu. Paris: Plon, FLC J418.

Colonna, Francisco (attrib.). (1499). Hypnerotomachia Poliphili. Venice: Aldus Manutius.

Corroyer, Édouard Jules. (1888). L'architecture romane. Paris: Quantin.

Doshi, Balkrishna V. (n.d.). Le Corbusier and Louis I. Kahn, The acrobat and the yogi of architecture. Ahmedabad: VastuShilpa Foundation for Studies and Research in Environmental Design.

Gresleri, Giuliano. (1984). Viaggio in Oriente. Venice: Marsilio.

Le Corbusier. (1926). Un standard meurt, un standard nait. Almanach d'architecture moderne. Paris: Crès.

Le Corbusier. (1925). La peinture moderne. Paris: Crès.

Le Corbusier. (1935). La ville radieuse. Boulogne: L'Architecture d'Aujourd'hui.

Le Corbusier. (1937). Le Corbusier \& P. Jeanneret: CFvre complète, 1910-1929, Zurich: Girsberger.

Le Corbusier. (1938). Le Corbusier \& P. Jeanneret: CFvre complète, 1934-1938. Zurich: Girsberger.

Le Corbusier. (1953). Evvre complète, 1946-1952. Zurich: Girsberger.

Le Corbusier. (1955) Poème de l'angle droit. Paris: Verve.

Le Corbusier. (1928). Une maison, un palais. À la recherche d'une unité architecturale. Paris: Crès.
Le Corbusier, Hôtel de Sully (Paris, France), Caisse nationale des monuments historiques et des sites (France), \& Ministère de la culture. (1988). Le Corbusier, le passé à réaction poétique. Catalogue of the exhibition held at the Hôtel de Sully, Paris.

Le Corbusier, Moos, Stanislaus von, Rüegg, Arthur, Stiftung "Langmatt" Sidney und Jenny Brown., \& Bard Graduate Center for Studies in the Decorative Arts. (2002). Le Corbusier before Le Corbusier: applied arts, architecture, painting, photography, 1907-1922. New Haven: Yale University Press.

Pallasmaa, Juhani. (2011). The embodied image. Imagination and imagery in architecture. Chichester: Wiley.

Vogt, Adolf Max. (1998). Le Corbusier, the noble savage. Toward an archaeology of modernism. Cambridge, Mass.: The MIT Press.

Von Moos, Stanislaus. (1987). Les femmes d'Alger. In Le Corbusier et la Méditerranée. Marseille: Parenthèses.

\section{CORRESPONDENCE}

Luis Burriel Bielza, Ecole Nationale Supérieure d'Architecture de Paris-Belleville, 60 Boulevard de la Villette, 75019 Paris, France

E-mail: Lburri@somosarquitectos.es

Published online, 2017

ISSN 1749-3463 print/ISSN 1749-3471

https://doi.org/10.14434/artifact.v4i1.13130

(C) 2017 Artifact 